\title{
Homeostatic Regulation of Serotonergic Function by the Serotonin Transporter As Revealed by Nonviral Gene Transfer
}

\author{
Véronique Fabre,, ${ }^{1}$ Benjamin Boutrel, ${ }^{1}$ Naïma Hanoun, ${ }^{1}$ Laurence Lanfumey, ${ }^{1}$ Claude Michelle Fattaccini, ${ }^{1}$ \\ Barbara Demeneix, ${ }^{2}$ Joëlle Adrien, ${ }^{1}$ Michel Hamon, ${ }^{1}$ and Marie-Pascale Martres ${ }^{1}$ \\ 1/nstitut National de la Santé et de la Recherche Médicale U288, Neuropsychopharmacologie Moléculaire, Cellulaire et \\ Fonctionnelle, Faculté de Médecine Pitié-Salpêtrière, 75634 Paris Cedex 13, France, and 2Laboratoire de Physiologie \\ Générale et Comparée, Unité de Recherche Associée 90, Centre National de la Recherche Scientifique, Museum National \\ d'Histoire Naturelle, 75231 Paris Cedex 5, France
}

\begin{abstract}
With the aim of exploring the relationship between the serotonin transporter (5-HTT or SERT) and the activity level of serotonin (5-HT) neurotransmission, in vivo expression of this protein was specifically altered using a nonviral DNA transfer method. Plasmids containing the entire coding sequence or a partial antisense sequence of the 5-HTT gene were complexed with the cationic polymer polyethylenimine and injected into the dorsal raphe nucleus of adult male rats. Significant increase or decrease in both $\left[{ }^{3} \mathrm{H}\right]$ citalopram binding and $\left[{ }^{3} \mathrm{H}\right] 5-\mathrm{HT}$ synaptosomal uptake were observed in various brain areas up to 2 weeks after a single administration of the sense plasmid or $7 \mathrm{~d}$ after injection of the short antisense plasmid, respectively. Such changes in 5-HTT expression were associated with functional alterations in 5-HT neurotransmission, as shown by the increased capacity of $5-\mathrm{HT}_{1 \mathrm{~A}}$ receptor stimulation to enhance
\end{abstract}

$\left[{ }^{35}\right.$ S]GTP- $\gamma$-S binding onto the dorsal raphe nucleus in sections from rats injected with the sense plasmid. Conversely, both a decrease in $5-\mathrm{HT}_{1 \mathrm{~A}}$-mediated $\left[{ }^{35} \mathrm{~S}\right] \mathrm{GTP}-\gamma$-S binding and a reduced potency of the $5-\mathrm{HT}_{1 \mathrm{~A}}$ receptor agonist ipsapirone to inhibit neuronal firing were observed in the dorsal raphe nucleus of antisense plasmid-injected rats. Furthermore, changes in brain 5-HT and/or 5-HIAA levels, and sleep wakefulness circadian rhythm in the latter animals demonstrated that altered expression of 5-HTT by recombinant plasmids has important functional consequences on central $5-\mathrm{HT}$ neurotransmission in adult rats.

Key words: nonviral gene transfer; 5-HT transporter-encoding plasmids; polyethylenimine; dorsal raphe nucleus; 5-HT ${ }_{1 A}$ receptor; 5-HT turnover; sleep
The serotonin (5-hydroxytryptamine, 5-HT) transporter (5-HTT or SERT) is responsible for reuptake of 5-HT released in the synaptic cleft as well as from the soma and/or dendrites of serotoninergic neurons in brain. Therefore, it is a key component of 5-HT neurotransmission by controlling both temporally and spatially the concentration of extracellular 5-HT in contact with specific receptors. The 5-HTT is the target of antidepressant drugs, in particular the so-called selective serotonin reuptake inhibitors (SSRIs) (Fuller et al., 1975; Thomas et al., 1987; Dechant and Clissold, 1991), which enhance 5-HT neurotransmission by increasing extracellular 5-HT levels (Auerbach and Hjorth, 1995; Invernizzi et al., 1995). In addition, 5-HTT functioning is directly affected by some drugs of abuse such as 3,4methylenedioxy-methamphetamine (MDMA or ecstasy) (Green

Received Sept. 23, 1999; revised Feb. 16, 2000; accepted April 11, 2000.

This work was supported by grants from Institut National de la Santé et de la Recherche Médicale, European Community (Biotech BIO4 CT960752), and BristolMyers Squibb Foundation (Unrestricted Biomedical Research Grant Program). We are grateful to D. Goula for expert advice in the performance of part of the study. V.F. was recipient of a Direction des Recherches, Etudes et Techniques fellowship during performance of the study. The generous gifts of drugs by pharmaceutical companies (Lilly, Wyeth-Ayerst) and of anti-5-HTT antibodies by Dr. F. C. Zhou (Indiana University School of Medicine, Indianapolis, IN) are gratefully acknowledged.

Correspondence should be addressed to Véronique Fabre, Institut National de la Santé et de la Recherche Médicale U288, Faculté de Médecine Pitié-Salpêtrière, 91 Boulevard de l'Hôpital, 75634 Paris cedex 13, France. E-mail:vfabre@scripps.edu.

Dr. Martres' present address: Institut National de la Santé et de la Recherche Médicale U513, Neurobiologie et Psychiatrie, Faculté de Médecine, 8 rue du Général Sarrail, 94010 Créteil, France.

Copyright (C) 2000 Society for Neuroscience $0270-6474 / 00 / 205065-11 \$ 15.00 / 0$ et al., 1995; Bengel et al., 1998). Indeed, recent studies emphasized the implication of 5-HT neurotransmission in the selfadministration (Rocha et al., 1998a; Sora et al., 1998) and the rewarding properties of cocaine (Rocha et al., 1998b) in mice.

Although drugs acting directly at the 5-HTT have been extensively used to assess the key role of this protein in the control of brain 5-HT neurotransmission, limitations in this approach are obvious because only inhibitors (such as SSRIs) or 5-HT releasers (through reverse functioning of the 5-HTT, such as MDMA) are available. An increased 5-HT reuptake has been reported to occur after in vivo treatment with tianeptine (Fattaccini et al., 1990; De Simoni et al., 1992), but this finding could not be confirmed by all authors (Pineyro et al., 1995a,b). In a previous study, we described the successful use of recombinant plasmids to either enhance or reduce the expression of the dopamine transporter (DAT) in the rat brain in vivo (Martres et al., 1998). A similar approach was used herein to either increase or decrease 5-HTT expression in the rat brain. For this purpose, recombinant plasmids containing sense or antisense coding sequences of the 5-HTT gene were complexed with a cationic polymer, polyethylenimine (PEI) (Abdallah et al., 1996), and injected directly into the dorsal raphe nucleus (DRN), in which the somas of the majority of serotoninergic neurons projecting to forebrain areas are located (Aghajanian and Bloom, 1967; Descarries et al., 1982). The resulting changes in 5-HTT expression were assessed by measuring the specific binding of $\left[{ }^{3} \mathrm{H}\right]$ citalopram, which is selectively recognized by the 5-HTT (D'Amato et al., 1987), and $\left[{ }^{3} \mathrm{H}\right] 5$-HT synaptosomal uptake in various brain areas. In addi- 
tion, the consequences of up- or down-expression of the 5-HTT on 5-HT neurotransmission were investigated by estimating 5-HT turnover, analyzing the binding and functional properties of $5-\mathrm{HT}_{1 \mathrm{~A}}$ receptors, and recording the sleep-wakefulness rhythm at various times after intra-DRN administration of the recombinant plasmids in adult rats.

\section{MATERIALS AND METHODS}

All experiments were performed in conformity with the institutional guidelines that are in compliance with national and international law and policies for use of animals in neuroscience research (council directive 87-848, October 1987, Ministère de l'Agriculture et de la Forêt, Service Vétérinaire de la Santé et de la Protection Animale; permissions 6269 to L.L., 0315 to J.A., 0299 to M.H., and 0905 to M.P.M). Unless otherwise indicated, rats were housed under standard laboratory conditions: $12 \mathrm{hr}$ light/dark cycle (lights on at 7:00 A.M.), $22 \pm 1^{\circ} \mathrm{C}$ ambient temperature, $60 \%$ relative humidity, food and water ad libitum.

\section{Constructions of recombinant plasmids}

For construction of the 5-HTT sense plasmid, a cDNA comprising the complete coding sequence of the rat 5-HTT (nucleotides 87-2400; Blakely et al., 1991) was subcloned into the pRc-CMV expression vector (Invitrogen, Leek, Netherlands) that contains the cytomegalovirus promoter and the bovine growth hormone $(\mathrm{BGH})$ polyadenylation signal. For the antisense constructs, either the entire coding sequence of 5-HTT (referred to as "full antisense"), or its last 468 nucleotides (nucleotides 1540-2007, "short antisense") were subcloned in their reverse orientation into the plasmid pRc-CMV (Fig. $1 A$ ). The nonrecombinant pRcCMV plasmid, containing only the polylinker (Invitrogen), was used as control. Plasmid DNAs were prepared by two successive centrif ugations in cesium chloride gradient, resuspended in $10 \mathrm{~mm}$ Tris- $\mathrm{HCl}$ and $1 \mathrm{~mm}$ EDTA, $\mathrm{pH} 8$, and quantified by their optical density (O.D.) at $260 \mathrm{~nm}$. Aliquots $(2.5-5.0 \mu \mathrm{g}$ of DNA/ $\mu \mathrm{l})$ were stored at $-20^{\circ} \mathrm{C}$ until use.

Cell line transfection and measurement of $\left[{ }^{3} \mathrm{H}\right] 5-\mathrm{HT}$ uptake in transfected cells

LLC-PK1 cells (pig kidney epithelial cells; American Type Culture Collection, Rockville, MD; CRL 1392) were grown under a $7 \% \mathrm{CO}_{2}$ and $93 \%$ air atmosphere at $37^{\circ} \mathrm{C}$ in DMEM supplemented with $10 \%$ fetal bovine serum, $2 \mathrm{~mm}$ glutamine, $10 \mathrm{U} / \mathrm{ml}$ penicillin $\mathrm{G}$, and $10 \mathrm{mg} / \mathrm{ml}$ streptomycin. DNA constructs were transfected into 50-60\% confluent cells by electroporation using an Equibio apparatus (Eurogentec, Seraing, Belgium; $3-5 \times 10^{6}$ cells in $500 \mu \mathrm{l}$ of DMEM without serum, $270 \mathrm{~V}$, $1800 \mu \mathrm{F}$, relaxation time, $40 \mathrm{msec}$ ). Twenty four hours after transfection, cells were transferred into 24 -well plates, and $24 \mathrm{hr}$ later the expression of 5-HTT was examined by measuring $\left[{ }^{3} \mathrm{H}\right] 5$-HT uptake, following a protocol adapted from Pifl et al. (1993). Briefly, cells were washed twice with $1 \mathrm{ml}$ of uptake buffer (4 mM Tris, $6.25 \mathrm{mM}$ HEPES, $120 \mathrm{~mm} \mathrm{NaCl}$, $5 \mathrm{~mm} \mathrm{KCl}, 1.2 \mathrm{~mm} \mathrm{CaCl}_{2}, 1.2 \mathrm{~mm} \mathrm{MgSO}_{4}, 5.6 \mathrm{~mm}$ glucose, and $0.5 \mathrm{~mm}$ ascorbic acid, final $\mathrm{pH} 7.4$ ) and then incubated in $500 \mu \mathrm{l}$ of uptake buffer containing 3-6 nм [ $\left.{ }^{3} \mathrm{H}\right] 5-\mathrm{HT}$ ( $15 \mathrm{Ci} / \mathrm{mmol}$; Amersham Pharmacia Biotech, Buckinghamshire, UK), without or with $10 \mu \mathrm{M}$ fluoxetine (Lilly, Indianapolis, IN) to determine nonspecific uptake. After $7 \mathrm{~min}$ at $37^{\circ} \mathrm{C}$, the reaction medium was drawn out, and cells were quickly washed three times with $1 \mathrm{ml}$ of uptake buffer at room temperature. Cells were then solubilized in $500 \mu \mathrm{l}$ of $0.1 \mathrm{~N} \mathrm{NaOH}$, and the entrapped radioactivity was counted by liquid scintillation spectrometry.

To correct for variations in the transfection yields, $2.5 \mu \mathrm{g}$ of a pRcCMV plasmid containing the entire coding sequence of the DAT gene (Martres et al., 1998) was cotransfected with the various plasmids. The uptake of $\left[{ }^{3} \mathrm{H}\right] \mathrm{DA}$ (46 Ci/mmol; Amersham Pharmacia Biotech) was measured as described by Pifl et al. (1993), with 3-6 nM [ $\left.{ }^{3} \mathrm{H}\right] \mathrm{DA}$, in the absence or the presence of $10 \mu \mathrm{M}$ nomifensine (Research Biochemicals, Natick, MA) to determine nonspecific uptake. Data normalized according to the respective $\left[{ }^{3} \mathrm{H}\right] \mathrm{DA}$ uptake are expressed as femtomoles of $\left[{ }^{3} \mathrm{H}\right] 5-\mathrm{HT}$ taken up per minute and per well.

\section{Intracerebral gene transfer and dissection}

Adult male Sprague Dawley rats (3 months old, 250-300 gm body weight; Centre d'Elevage R. Janvier, Le Genest-St Isle, France) were anesthetized with chloral hydrate $(400 \mathrm{mg} / \mathrm{kg}$, i.p.) and positioned in a stereotaxic apparatus (David Kopf, Phymep, Paris, France). The needle (outer diameter, $0.46 \mathrm{~mm}$ ) of a $10 \mu \mathrm{l}$ Hamilton syringe was lowered into the
A

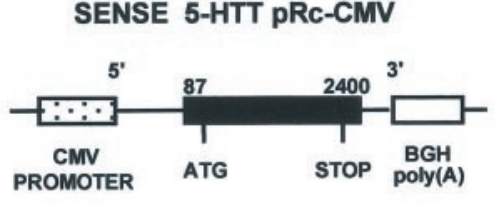

FULL ANTISENSE 5-HTT pRC-CMV

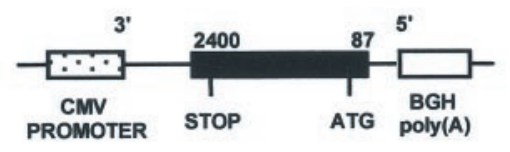

SHORT ANTISENSE 5-HTT pRc-CMV
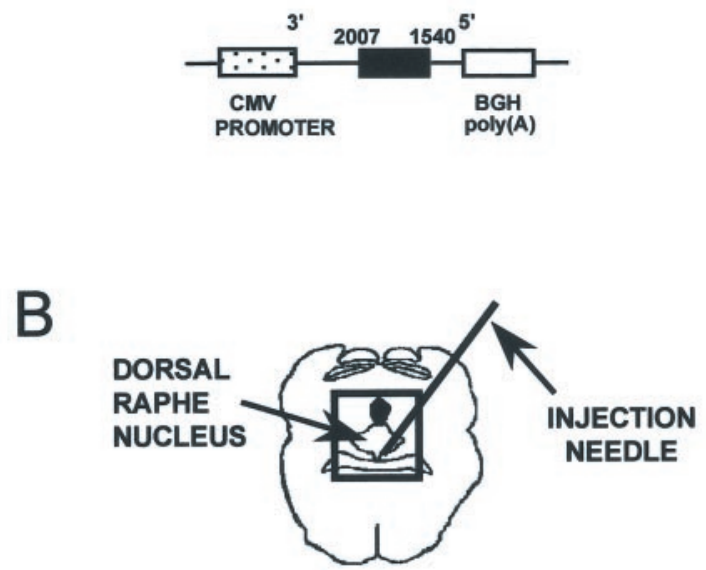

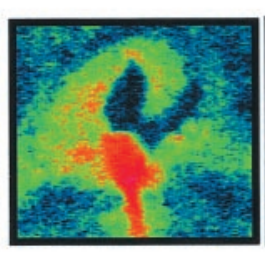

SENSE

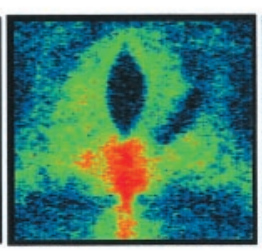

CONTROL

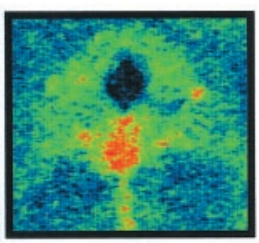

ANTISENSE
Figure 1. Plasmid constructs and autoradiographic labeling of 5-HTT. A, Expression vectors for sense and full and short antisense 5-HTT. $B G H$, Bovine growth hormone. All in vivo experiments were performed with the short antisense 5-HTT pRc-CMV. B, Examples of color-coded autoradiographic labeling of 5-HTT in the dorsal raphe nucleus after local injection of sense, short antisense, or control (nonrecombinant) plasmid. Coronal sections $(20 \mu \mathrm{m})$ were labeled by $\left[{ }^{3} \mathrm{H}\right]$ citalopram $(0.7 \mathrm{nM})$ at the level of the dorsal raphe nucleus, $3 \mathrm{~d}$ after administration of the sense plasmid ("sense") or $7 \mathrm{~d}$ after that of the short antisense plasmid ("antisense"). "Control" represents a typical example of labeling obtained $3 \mathrm{~d}$ after injection of the nonrecombinant plasmid-PEI complex (similar autoradiographic labeling was observed on the seventh day after "control" injection). The color code indicates increasing O. D. values from blue, green, and yellow, to red.

DRN (angle, $32^{\circ} \mathrm{C}$; anterior $=0.12 \mathrm{~cm}$; lateral $=0.40 \mathrm{~cm}$; horizontal $=$ $0.28 \mathrm{~cm}$ from the interaural zero, according to the stereotaxic atlas of Paxinos and Watson, 1986). After 2 min, $2 \mu$ l of a $5 \%$ glucose solution containing $0.5 \mu \mathrm{g}$ of plasmid DNA mixed with linearized $22 \mathrm{kDa}$ PEI (generous gift of J. P. Behr) at six charge equivalents (Martres et al., 1998) were manually injected over $5 \mathrm{~min}$. The needle was left in place for a further $5 \mathrm{~min}$ to limit the diffusion before its removal. Paired-control 
rats received the nonrecombinant $\mathrm{pRc}-\mathrm{CMV}$ plasmid under the same conditions of complexation with PEI.

At various times (up to $28 \mathrm{~d}$ after injection), animals were decapitated, and their brains were removed. The hypothalamus was dissected out, and a coronal cut was made at an interaural anteriority of $\sim 0.50 \mathrm{~cm}$ (Paxinos and Watson, 1986). The posterior part of the brain was frozen by immersion in isopentane at $-30^{\circ} \mathrm{C}$ and the hippocampi, the striata, and the anterior cortex were dissected out for the preparation of synaptosomes and for binding experiments. For immunoautoradiographic experiments, rats were anesthetized with pentobarbital $(60 \mathrm{mg} / \mathrm{kg}$, i.p.) and perfused transcardially with $300 \mathrm{ml}$ of $0.9 \% \mathrm{NaCl}$ supplemented with $0.1 \% \mathrm{NaNO}_{2}$. After decapitation, the brain was removed and frozen as described above.

\section{Quantitative autoradiography}

$\left[{ }^{3}\right.$ H]Citalopram. Coronal sections $(20 \mu \mathrm{m})$ at the level of the DRN were cut at $-20^{\circ} \mathrm{C}$, thaw-mounted onto gelatin-coated slides, and then stored at $-20^{\circ} \mathrm{C}$ until use. For the labeling procedure, slides were first brought to room temperature during $15 \mathrm{~min}$ and then preincubated for $15 \mathrm{~min}$ in $50 \mathrm{~mm}$ Tris- $\mathrm{HCl}$ buffer containing $120 \mathrm{~mm} \mathrm{NaCl}$ and $5 \mathrm{~mm} \mathrm{KCl}, \mathrm{pH} 7.4$, at $25^{\circ} \mathrm{C}$. Incubations proceeded for $1 \mathrm{hr}$ at $25^{\circ} \mathrm{C}$ in fresh Tris buffer with $0.7 \mathrm{~nm}\left[{ }^{3} \mathrm{H}\right]$ citalopram $(85 \mathrm{Ci} / \mathrm{mmol}$; DuPont NEN, Boston, MA). Nonspecific binding was estimated from adjacent sections incubated in the same medium supplemented with $10 \mu \mathrm{M}$ fluoxetine. The sections were then washed twice for 5 min each in the Tris buffer at $4^{\circ} \mathrm{C}$. They were dried in a stream of cold air and apposed to ${ }^{3} \mathrm{H}$-Hyperfilm (Amersham) for $4 \mathrm{~d}$ at $4^{\circ} \mathrm{C}$. Optical density on the autoradiograms was measured using a computerized image analysis system (Biocom, Les Ulis, France) and converted to femtomoles of $\left[{ }^{3} \mathrm{H}\right]$ citalopram specifically bound per milligram of tissue according to a ${ }^{3} \mathrm{H}$ standard scale (Amersham).

$\left[{ }^{35} S / G T P-\gamma-S\right.$. Autoradiography of agonist-stimulated $\left[{ }^{35} \mathrm{~S}\right] \mathrm{GTP}-\gamma-\mathrm{S}$ binding was performed as described (Sim et al., 1996; Waeber and Moskowitz, 1997; Dupuis et al., 1998). Briefly, $20 \mu \mathrm{m}$ brain sections were preincubated at $25^{\circ} \mathrm{C}$ for $15 \mathrm{~min}$ in $50 \mathrm{~mm}$ HEPES, $\mathrm{pH} 7.5$, containing $100 \mathrm{~mm} \mathrm{NaCl}, 3 \mathrm{~mm} \mathrm{MgCl}, 0.2 \mathrm{~mm}$ EGTA, and $0.2 \mathrm{~mm}$ dithiothreitol, and then incubated for $15 \mathrm{~min}$ in the same buffer supplemented with 2 mM GDP (Boehringer Mannheim, Meylan, France) and $10 \mu \mathrm{M}$ of 8-cyclopentyl-1,3-dipropylxanthine (CPDPX; Research Biochemicals), an adenosine receptor antagonist, to reduce nonspecific binding (Laitinen and Jokinen, 1998). Thereafter, sections were incubated for $1 \mathrm{hr}$ at $30^{\circ} \mathrm{C}$ in the same buffer with $0.05 \mathrm{~nm}\left[{ }^{35} \mathrm{~S}\right] \mathrm{GTP}-\gamma-\mathrm{S}(1000 \mathrm{Ci} / \mathrm{mmol}$; Amersham) supplemented (stimulated conditions) or not (basal conditions) with $10 \mu \mathrm{M}$ 5-carboxamido-tryptamine (5-CT; Research Biochemicals). Nonspecific binding was determined on autoradiograms from adjacent sections incubated with $10 \mu \mathrm{M}$ 5-CT plus $10 \mu \mathrm{M}$ WAY 100635 (Wyeth-Ayerst, Princeton, NJ). Optical density on the autoradiograms was measured using a computerized image analysis system (Biocom).

\section{Immunoautoradiography with anti-5-HTT, anti-DAT, or anti-5- $H T_{1 A}$ receptor antibodies}

Polyclonal antibodies specific to the third intracytoplasmic loop of the rat $5-\mathrm{HT}_{1 \mathrm{~A}}$ receptor (El Mestikawy et al., 1990), or to the N-terminal domain of the rat DAT (Martres et al., 1998) or the rat 5-HTT (Zhou et al., 1996), were used according to a protocol adapted from Gérard et al. (1994). Coronal sections $(20 \mu \mathrm{m})$ were fixed for 3 min with $4 \%$ paraformaldehyde in PBS (50 mM NaH $\mathrm{PO}_{4} / \mathrm{Na}_{2} \mathrm{HPO}_{4}, 154 \mathrm{~mm} \mathrm{NaCl}, \mathrm{pH} 7.4$ ) at $4^{\circ} \mathrm{C}$, then preincubated for $1 \mathrm{hr}$ in PBS supplemented with $3 \%$ bovine serum albumin and $1 \%$ donkey serum, and incubated overnight at $4^{\circ} \mathrm{C}$ with affinity-purified anti-5- $\mathrm{HT}_{1 \mathrm{~A}}$ receptor antibodies at 1:5000 dilution, anti-DAT antibodies at 1:20,000 dilution, or anti-5-HTT antibodies at 1:5000 dilution. After extensive washes, sections were incubated for $2 \mathrm{hr}$ at room temperature in a solution of donkey anti-rabbit [ $\left.{ }^{125} \mathrm{I}\right] \operatorname{IgG}(750-$ $3000 \mathrm{Ci} / \mathrm{mmol}$; Amersham), then washed, dried in a stream of cold air, and apposed to $\beta$ max films (Amersham) for $2-5 \mathrm{~d}$. Optical density on the immunoradiograms was measured using a computerized image analysis system (Biocom).

\section{$\left[{ }^{3} H\right] 5$-HT synaptosomal uptake}

The hypothalamus, hippocampi, striata and anterior cortex were homogenized in 15-20 volumes (v/w) of $0.32 \mathrm{M}$ sucrose with a glass-Teflon potter (Heidolf, Bioblock, Illkirch, France). Homogenates were diluted to $40 \mathrm{vol}$ with $0.32 \mathrm{M}$ sucrose, centrifuged at $1000 \times g$ for $10 \mathrm{~min}$, and the resulting supernatants were centrifuged again at $10,000 \times \mathrm{g}$ for $30 \mathrm{~min}$. The pellets were gently resuspended in $50 \mathrm{vol}$ of $0.32 \mathrm{M}$ sucrose, and 25 $\mu \mathrm{l}$ aliquots of each suspension were incubated in $500 \mu \mathrm{l}$ of uptake buffer containing 3-6 nM $\left[{ }^{3} \mathrm{H}\right] 5-\mathrm{HT}$, without or with $10 \mu \mathrm{M}$ fluoxetine to determine nonspecific uptake. After $7 \mathrm{~min}$ at $37^{\circ} \mathrm{C}$, samples were diluted with $3 \mathrm{ml}$ of ice-cold uptake buffer and rapidly filtered through Whatman GF/B glass-fiber filters presoaked with $0.05 \%$ PEI. After three washes with $3 \mathrm{ml}$ of ice-cold uptake buffer, filters were dried, and the entrapped radioactivity was counted by liquid scintillation spectrometry.

\section{$\left[{ }^{3} H\right]$ Citalopram membrane binding}

Dissected tissues (various forebrain regions and the anterior raphe area) were homogenized in 40 volumes $(\mathrm{v} / \mathrm{w})$ of ice-cold $50 \mathrm{~mm}$ Tris-HCl

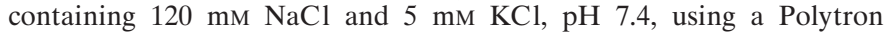
disrupter (type PT 10 OD; Touzart-Matignon, Vitry-sur-Seine, France). Homogenates were centrifuged at $40,000 \times g$ for $20 \mathrm{~min}$, and the pellets were resuspended in $40 \mathrm{vol}$ of the same buffer, then incubated at $37^{\circ} \mathrm{C}$ for 10 min to remove endogenous 5 -HT. The membranes were spun down at $40,000 \times g$ for $20 \mathrm{~min}$ and washed another three times by resuspension/ centrifugation as before. The final pellet was suspended in $10 \mathrm{vol}$. of the same buffer, and aliquots $(25 \mu \mathrm{l})$ were incubated in the above buffer (final volume of $0.5 \mathrm{ml}$ ) with $0.7 \mathrm{nM}$ or various concentrations $(0.2-5.7 \mathrm{nM})$ of $\left[{ }^{3} \mathrm{H}\right]$ citalopram. Nonspecific binding was determined in the presence of $10 \mu \mathrm{M}$ fluoxetine. After $1 \mathrm{hr}$ at $25^{\circ} \mathrm{C}$, samples were diluted with $3 \mathrm{ml}$ of ice-cold buffer and rapidly filtered through Whatman GF/B filters presoaked with $0.05 \%$ PEI. The filters were dried, and the entrapped radioactivity was counted by liquid scintillation spectrometry. Kinetic parameters of $\left[{ }^{3} \mathrm{H}\right]$ citalopram-specific binding were calculated using the program "LIGAND" (McPherson, 1985).

\section{Measurements of tissue levels of 5-HT, DA, and their respective metabolites}

Aliquots $(200 \mu \mathrm{l})$ of homogenates in $0.32 \mathrm{M}$ sucrose (prepared for the measurement of $\left[{ }^{3} \mathrm{H}\right] 5-\mathrm{HT}$ uptake $)$ were mixed with $\mathrm{HClO}_{4}(0.1 \mathrm{M}$ final), $\mathrm{Na}_{2} \mathrm{~S}_{2} \mathrm{O}_{5}(0.05 \% \mathrm{w} / \mathrm{v})$, and disodium EDTA $(0.05 \% \mathrm{w} / \mathrm{v})$, and centrifuged at $30,000 \times g$ for $15 \mathrm{~min}$ at $4^{\circ} \mathrm{C}$. The supernatants were neutralized with $2 \mathrm{M} \mathrm{KH}_{2} \mathrm{PO}_{4} / \mathrm{K}_{2} \mathrm{HPO}_{4}, \mathrm{pH} 7.4$, supplemented with ascorbate oxidase (Boehringer; final concentration $0.01 \mathrm{mg} / \mathrm{ml}$ ), and $\mathrm{KClO}_{4}$ precipitate was removed by centrifugation at $30,000 \times g$ for $10 \mathrm{~min}$ at $4^{\circ} \mathrm{C}$. Aliquots $(10 \mu \mathrm{l})$ of the clear supernatants were injected directly into an HPLC column (Ultrasphere IP; Beckman, Gagny, France; $25 \mathrm{~cm} \times 4.6$ $\mathrm{cm}, \mathrm{C} 18$ reverse-phase, particle size $5 \mu \mathrm{m})$ protected with a Brownlee precolumn. The mobile phase (at a flow rate of $1 \mathrm{ml} / \mathrm{min}$ ) consisted of 70 $\mathrm{mM} \mathrm{KH}_{2} \mathrm{PO}_{4}, 2.1 \mathrm{~mm}$ triethylamine, $0.1 \mathrm{~mm}$ disodium EDTA, $1.25 \mathrm{~mm}$ octane sulfonate, and $16 \%$ methanol, adjusted to $\mathrm{pH} 3.02$ with solid citric acid (Hamon et al., 1988). The electrochemical detection system (ESA 5011; Collaborative Research, Bedford, MA) comprises an analytical cell with dual coulometric monitoring electrodes $(+50 \mathrm{mV}$ and +350 $\mathrm{mV}$ ). The generated signal was integrated by a computing integrator (System-Gold Beckman). Quantitative determinations of 5-HT and its metabolite 5-hydroxyindoleacetic acid (5-HIAA) and of DA and its metabolite dihydroxyphenylacetic acid (DOPAC) were made with reference to pure standards (Hamon et al., 1988).

\section{Protein concentrations}

Proteins were quantified using the method of Lowry et al. (1951) with bovine serum albumin as standard.

\section{Electrophysiological studies}

Young male Sprague Dawley rats ( 100 gm body weight) were used in these experiments because brain tissues from young animals were more resistant than those from adults to hypoxia occurring for the preparation of brain slices (Di Scenna, 1987). Rats were decapitated $8 \mathrm{~d}$ after intra-DRN injection of recombinant or nonrecombinant plasmids as described above. The brain was removed rapidly and placed in an ice-cold Krebs' solution continuously bubbled with carbogen $\left(95 \% \mathrm{O}_{2}\right.$ and $5 \% \mathrm{CO}_{2}$ ). A block of tissue containing the DRN was sliced using a vibratome at $4^{\circ} \mathrm{C}$. Slices $(400-\mu \mathrm{m}$-thick) were maintained at room temperature in an artificial CSF for $1 \mathrm{hr}$ and then transferred to a recording chamber. Extracellular recordings were made with glass microelectrodes (filled with $2 \mathrm{M} \mathrm{NaCl}$; impedance, $10-15 \mathrm{M} \Omega$ ) introduced into the DRN area, as described in detail elsewhere (Haj-Dahmane et al., 1991). After identification of the cells as serotoninergic neurons (VanderMaelen and Aghajanian, 1983), basal activity was recorded before application of the 5- $\mathrm{HT}_{1 \mathrm{~A}}$ receptor agonist ipsapirone (Haj-Dahmane et al., 1991), at $10-1000 \mathrm{~nm}$. This drug was added to the superfusing fluid for $3 \mathrm{~min}$, and 
the resulting changes in firing rate of the recorded neurons were computed and recorded graphically.

\section{Analysis of sleep-wakefulness recordings}

For the study of the sleep-wakefulness rhythms, adult male Sprague Dawley rats were first injected into the DRN area with recombinant or nonrecombinant plasmids as described above. Immediately after completion of the injection, animals were implanted with the classical set of electrodes (made of enameled nichrome wire, $150 \mu \mathrm{m}$ in diameter) for polygraphic sleep monitoring as described elsewhere (Maudhuit et al., 1994). In brief, two electrodes were inserted through the skull onto the dura over the right frontal and occipital cortex to record the electroencephalogram (EEG), two electrodes were positioned subcutaneously on each side of the orbit for the electrooculogram (EOG), and two electrodes were inserted into the neck muscles for recording the electromyogram (EMG). All electrodes were anchored to the skull with acrylic cement and soldered to a mini-connector also embedded in cement. After completion of surgery, animals were housed in individual recording cages and allowed to recover for $6 \mathrm{~d}$ under standard laboratory conditions. They were then connected to the recording cables for a $2 \mathrm{~d}$ habituation to the recording conditions. Recordings were obtained during 24 consecutive $\mathrm{hr}$ on the eighth day after injection of the plasmids. Polygraphic recordings were scored manually every $30 \mathrm{sec}$ epoch, and data were fed into a computer, as described elsewhere (Adrien et al., 1991). For each animal, the amounts of wakefulness (W), slow wave sleep (SWS), and rapid eye movement sleep (REMS) were calculated over $3 \mathrm{hr}$ periods throughout $24 \mathrm{hr}$. The mean of these amounts (expressed as min \pm SEM) for each group of rats was then used for statistical analysis.

After completion of the recording session, rats were decapitated, and their brains were removed. The hypothalamus was dissected out for the measurement of $\left[{ }^{3} \mathrm{H}\right] 5-\mathrm{HT}$ synaptosomal uptake, and the rest of the brain was frozen in isopentane at $-30^{\circ} \mathrm{C}$ for binding and autoradiography experiments as described above.

\section{Statistical calculations}

Comparison between groups was first made using ANOVA, and in case of significance, the Student's $t$ test was used to compare values for rats injected with recombinant constructs with those for paired-control rats (injected with the nonrecombinant pRc-CMV).

\section{RESULTS}

\section{Plasmid efficiency in LLC-PK1 cells}

To test the efficiency of the different plasmid constructs, the epithelial cell line LLC-PK1, which does not express the 5-HTT, was transiently transfected with the sense plasmid $(5 \mu \mathrm{g})$ alone or together with each antisense plasmid $(25 \mu \mathrm{g})$. Measurement of $\left[{ }^{3} \mathrm{H}\right] 5-\mathrm{HT}$ uptake showed that the sense construct allowed the expression of a functional 5-HTT $\left(120 \pm 15\right.$ fmol of $\left[{ }^{3} \mathrm{H}\right] 5-\mathrm{HT}$ taken up per well and per minute, with $5 \mathrm{~nm}\left[{ }^{3} \mathrm{H}\right] 5-\mathrm{HT}$; data not shown; mean $\pm \mathrm{SEM} ; n=15)$, the activity of which could be inhibited by cotransfection with either antisense construct. The short antisense construct exhibited the greatest efficacy $(58 \%$ inhibition as compared to $23 \%$ for the full antisense plasmid; data not shown). Thus, the recombinant plasmid with the short antisense sequence was used in subsequent experiments aimed at decreasing 5-HTT expression in the rat brain. As expected from their selectivity, neither the short antisense plasmid nor the long one significantly affected $\left[{ }^{3} \mathrm{H}\right] \mathrm{DA}$ uptake induced by cotransfection with a pRc-CMV plasmid encoding DAT (data not shown).

\section{5-HTT protein expression in the dorsal raphe nucleus after sense or antisense plasmid injection}

Previous studies showed that DAT was overexpressed as soon as the third day after injection of a sense plasmid in the rat brain, whereas a significant decrease in DAT expression was first observed on the seventh day after injection of an antisense plasmid (Martres et al., 1998). The same time intervals after intra DRN injection of recombinant sense or antisense 5-HTT encoding plasmids were selected in a first series of experiments.
As illustrated in Figure $1 B$, a significant increase $(+23 \pm 7 \%$; $n=6 ; p<0.01)$ in the specific labeling of the DRN by $\left[{ }^{3} \mathrm{H}\right]$ citalopram was observed $3 \mathrm{~d}$ after local administration of the sense construct. In contrast, a clear cut decrease in $\left[{ }^{3} \mathrm{H}\right]$ citalopram binding onto the DRN $(-28 \pm 3 \% ; n=6 ; p<0.01)$ was noted $7 \mathrm{~d}$ after injection of the short antisense construct (Fig. 1B). On the other hand, except along the trace of the injection needle (Fig. $1 B)$, the specific labeling of the DRN by $\left[{ }^{3} \mathrm{H}\right]$ citalopram did not differ between non recombinant $\mathrm{pRc}-\mathrm{CMV}$-injected rats and intact control animals (data not shown).

\section{5-HTT expression and activity in forebrain areas of sense or antisense plasmid-injected rats}

Significant increases (by $10-29 \%$ ) in $\left[{ }^{3} \mathrm{H}\right] 5-\mathrm{HT}$ synaptosomal uptake were observed in all forebrain areas studied $3 \mathrm{~d}$ after intra-DRN administration of the sense plasmid (Fig. 2, top). In contrast, significant decreases (by -24 to $31 \%$ ) in $\left[{ }^{3} \mathrm{H}\right] 5-\mathrm{HT}$ uptake were found in the same areas on the seventh day after antisense plasmid injection (Fig. 2, bottom). As illustrated in Figure 2, the largest changes after administration of either recombinant plasmid were noted in the hypothalamus. On the other hand, $\left[{ }^{3} \mathrm{H}\right] 5$-HT uptake in rats injected with the pRc-CMV nonrecombinant plasmid complexed with PEI was not significantly different from that measured using synaptosomes from noninjected control animals (noninjected controls, $290 \pm 18 \mathrm{fmol}$ $\left[{ }^{3} \mathrm{H}\right] 5-\mathrm{HT}$ taken up per milligram of protein; nonrecombinant $\mathrm{pRc}-\mathrm{CMV}$-injected rats, $268 \pm 12 \mathrm{fmol} / \mathrm{mg}$ protein, as compared with $219 \pm 7 \mathrm{fmol} / \mathrm{mg}$ protein in rats injected with the antisense plasmid in the very same experiment; $n=5$ in each group; $p<$ 0.01 for the latter group as compared with the other two groups).

Quantification of the 5-HTT protein with $\left[{ }^{3} \mathrm{H}\right]$ citalopram as selective radioligand also showed a significant increase $(+17-$ $23 \%$ ) in the four brain areas studied in rats injected with the sense plasmid (Fig. 2, top). On the contrary, the specific binding of $\left[{ }^{3} \mathrm{H}\right]$ citalopram in the same regions was decreased ( -10 to $\left.25 \%\right)$ on the third (data not shown) as well as on the seventh day (Fig. 2 , bottom) after intra-DRN injection of the short antisense construct. Comparison of the quantitative changes in $\left[{ }^{3} \mathrm{H}\right] 5-\mathrm{HT}$ uptake and $\left[{ }^{3} \mathrm{H}\right]$ citalopram-specific binding indicated a relatively good parallelism between them. The only exception was the striatum where the reduction in $\left[{ }^{3} \mathrm{H}\right] 5$-HT uptake $(-25 \pm 5 \%$; $n=15 ; p<0.005)$ was larger than that in $\left[{ }^{3} \mathrm{H}\right]$ citalopram-specific binding $(-10 \pm 3 \% ; n=15 ; p<0.05)$. Saturation studies performed with membranes from the anterior cortex showed that the $B_{\max }$ of $\left[{ }^{3} \mathrm{H}\right.$ ]citalopram binding was decreased by $40 \%$ in rats injected with the short antisense plasmid as compared with paired-control rats injected with the pRc-CMV nonrecombinant plasmid. In contrast, similar $K_{\mathrm{d}}$ values were found in both groups of rats. These observations were made at both $3 \mathrm{~d}$ (data not shown) and $7 \mathrm{~d}$ (Fig. 3) after intra-DRN administration of the plasmids.

Further studies were performed with antibodies that recognize specifically 5-HTT or DAT to assess both the amplitude and the specificity of the changes induced by intra-DRN injection of sense or antisense recombinant plasmid. Quantification of immunoautoradiograms (Fig. $4 A$ ) showed a $26 \%$ increase $(p<0.05)$ or a $23 \%$ decrease $(p<0.05)$ in DRN labeling by anti-5-HTT antibodies $7 \mathrm{~d}$ after intra-DRN injection of sense or antisense construct, respectively (relative O.D. values were $14.4 \pm 0.6$ and $8.8 \pm 0.5$ after sense and antisense plasmid administration, respectively, as compared with $11.4 \pm 0.6$ in paired-control rats injected with nonrecombinant $\mathrm{pRc}-\mathrm{CMV} ; n=4$ in each group). 


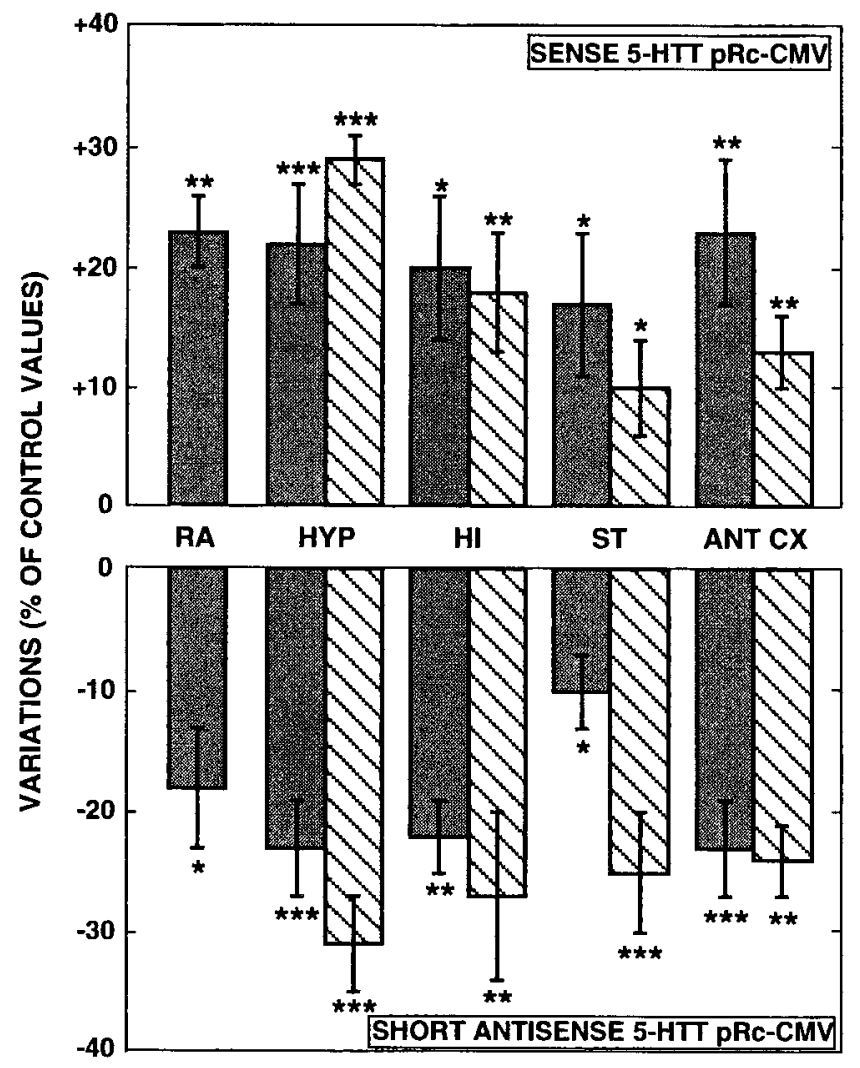

$\left[{ }^{3} \mathrm{H}\right]$ CITALOPRAM BINDING
$\square\left[{ }^{3} \mathrm{H}\right] 5-\mathrm{HT}$ UPTAKE

Figure 2. Effects of sense or antisense plasmid administration on 5-HTT activity and levels. $\left[{ }^{3} \mathrm{H}\right] 5-\mathrm{HT}$ synaptosomal uptake was measured in the hypothalamus $(H Y P)$, the hippocampus $(H I)$, the striatum $(S T)$, and the anterior cortex (ANT CX), $3 \mathrm{~d}($ top ) or $7 \mathrm{~d}$ (bottom) after intra-DRN injection of sense or antisense construct, respectively. Membrane binding assays were performed with $0.7 \mathrm{~nm}\left[{ }^{3} \mathrm{H}\right]$ citalopram in the same brain regions and in the anterior raphe area $(R A)$. Variations in both parameters are expressed as percentage of control values (rats injected with the nonrecombinant pRc-CMV and killed 3 or $7 \mathrm{~d}$ later). Data are the means \pm SEM of values in three independent experiments, each performed with five rats. Control values for $\left[{ }^{3} \mathrm{H}\right] 5-\mathrm{HT}$ uptake, in femtomoles per minute per milligram of protein are: $255 \pm 11(H Y P), 136 \pm 9(H I)$, $210 \pm 7(S T)$, and $227 \pm 8(A N T C X)$. Control values for $\left[{ }^{3} \mathrm{H}\right]$ citalopram specific binding, in femtomoles per milligram of protein are: $228 \pm 21$ $(R A), 365 \pm 20(H Y P), 155 \pm 9(H I), 264 \pm 14(S T)$, and $226 \pm 21(A N T$ $C X)$. ${ }^{*} p<0.05$; ${ }^{* *} p<0.01$; ${ }^{* * *} p<0.005$ as compared with pairedcontrol rats (Student's $t$ test).

In contrast, no changes in the immunolabeling of DAT were observed in the DRN (data not shown), the substantia nigra (a DA cell bodies-rich region), and the striatum (containing a high density of DA terminals) of the same recombinant plasmidinjected rats as compared with the same paired-control animals (Fig. 4B).

\section{Time course of 5-HTT overexpression after sense plasmid injection}

This study was performed using hypothalamic synaptosomes because the first series of experiments showed that the increase in $\left[{ }^{3} \mathrm{H}\right] 5-\mathrm{HT}$ uptake resulting from intra-DRN injection of the sense plasmid was the highest in the hypothalamus (Fig. 2). As illustrated in Figure 5, an elevated $\left[{ }^{3} \mathrm{H}\right] 5$-HT uptake capacity similar to that previously noted on the third day was observed on the

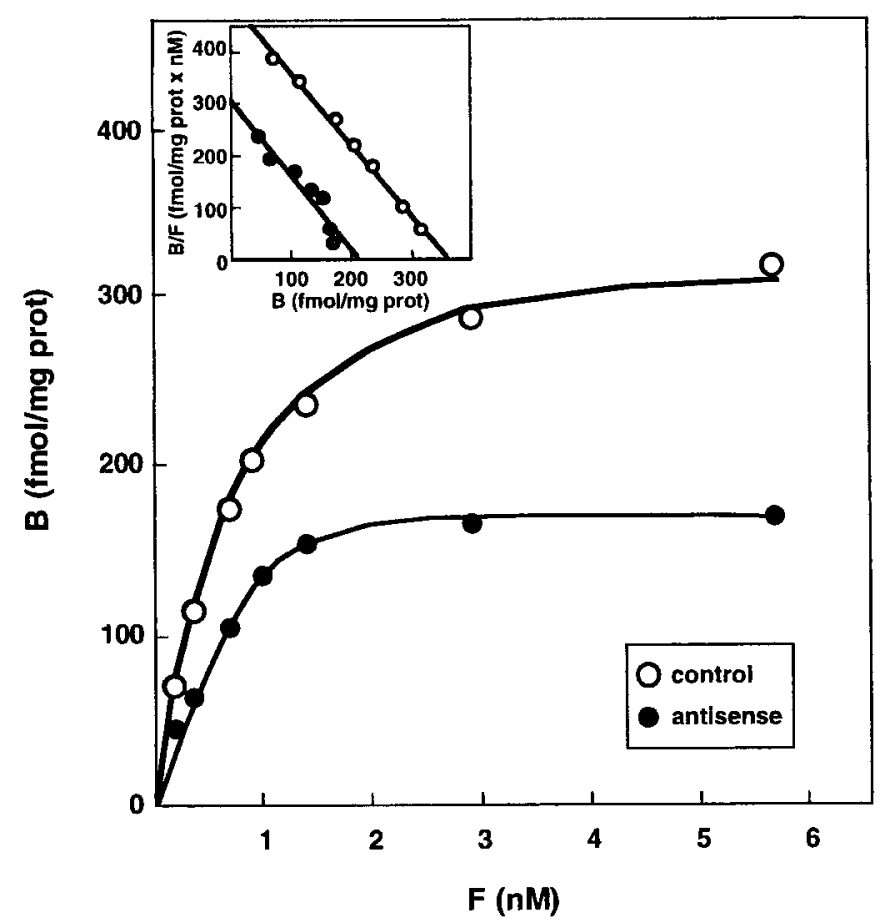

Figure 3. Effects of intra-DRN injection of antisense plasmid on $\left[{ }^{3} \mathrm{H}\right]$ citalopram binding to anterior cortex membranes. Saturation studies were performed with various concentrations of $\left[{ }^{3} \mathrm{H}\right]$ citalopram $(0.2-5.7$ $\mathrm{nM}), 7 \mathrm{~d}$ after injection of the antisense plasmid (antisense) or of the nonrecombinant plasmid (control). Each point is the mean of quadruplicate determinations in a typical representative experiment. Inset, Scatchard plot conversion of the data $\left(B,\left[{ }^{3} \mathrm{H}\right]\right.$ citalopram specifically bound; $F$, free $\left[{ }^{3} \mathrm{H}\right]$ citalopram, in nanomolar concentration). Similar data have been obtained in three independent experiments.

seventh day after the treatment. After 2 weeks, a significant increase was still found, but its amplitude was less than that measured earlier. At the last time studied, i.e., 4 weeks after intra-DRN injection, $\left[{ }^{3} \mathrm{H}\right] 5-\mathrm{HT}$ uptake did not significantly differ whether the rats were injected with the sense plasmid or the nonrecombinant pRc-CMV. Indeed, $\left[{ }^{3} \mathrm{H}\right] 5$-HT uptake capacity in rats injected with the latter vector remained at the same level as that measured in control untreated rats over the whole experimental period (Fig. 5).

\section{Levels of 5-HT, DA, and their respective metabolites after intra-DRN injection of the sense or the antisense construct}

Three days after injection of the sense construct, 5-HT levels were significantly increased in the hippocampus $(+16 \%)$, whereas they remained unaffected in the hypothalamus (Table 1). In contrast, 5-HIAA levels were significantly increased $(+33 \%)$ in the latter but not the former area. As a result, a significant elevation of the 5-HIAA/5-HT ratio was noted in the hypothalamus of sense plasmid-injected rats (Table 1). Measurements in the other two areas examined, the striatum and the anterior cortex, revealed no significant effects of the treatment as both 5-HT and 5-HIAA levels were similar to those found in control rats injected with the pRc-CMV nonrecombinant vector. With regard to DA and DOPAC levels in these same four brain areas, the only significant change concerned the hypothalamus, where an increase in DOPAC levels was noted on the third day $(+39 \pm 7 \% ; n=7 ; p<$ $0.005)$ after intra-DRN injection of the sense plasmid.

Three days (data not shown) as well as $7 \mathrm{~d}$ after intra-DRN 


\section{SENSE CONTROL ANTISENSE}

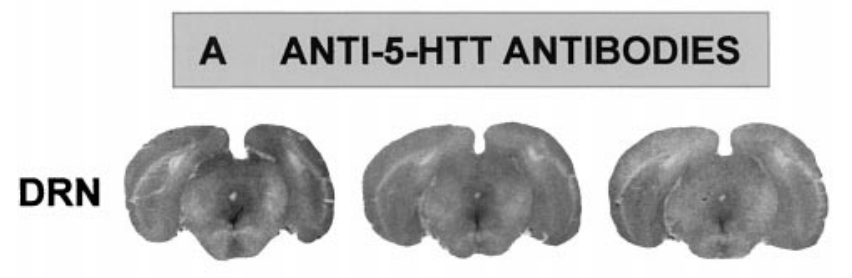

B ANTI-DAT ANTIBODIES

SN
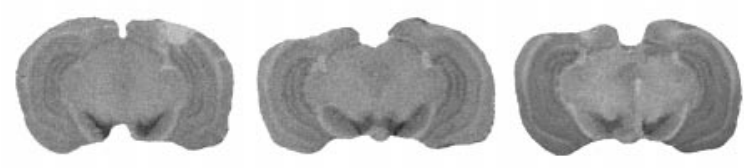

STR
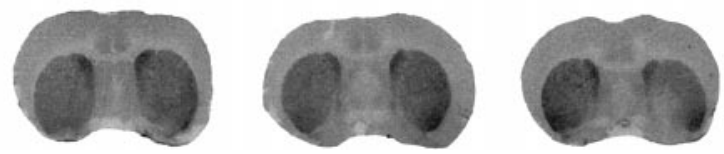

Figure 4. Immunoautoradiographic labeling of the 5-HTT and the DAT after intra-DRN injection of sense, antisense, or nonrecombinant (control) construct. Immunoautoradiographic labeling of coronal sections (20 $\mu \mathrm{m})$ with polyclonal anti-5-HTT- or anti-DAT-antibodies was performed $7 \mathrm{~d}$ after intra-DRN injection of each plasmid. $A$, Representative immunoautoradiograms of sections labeled by anti-5-HTT antibodies at the level of the dorsal raphe nucleus $(D R N)$. B, Representative immunoautoradiograms of sections labeled by anti-DAT antibodies at the level of the substantia nigra $(S N)$ or the striatum $(S T R)$. Similar data have been obtained in three rats in each group.

injection of the short antisense plasmid, a significant decrease in 5-HT levels was observed in the hypothalamus and the hippocampus (Table 1), but not in the striatum and the anterior cortex (data not shown). In contrast, 5-HIAA levels in the four brain areas studied were not significantly affected. Accordingly, the 5-HIAA/ 5-HT ratio in both the hypothalamus and the hippocampus was higher in antisense plasmid-injected rats than in paired controls (Table 1). On the other hand, neither DA nor DOPAC levels in the four brain areas studied significantly differed between the two groups of rats at $3 \mathrm{~d}$ as well as $7 \mathrm{~d}$ after injection (data not shown).

\section{5- $\mathrm{HT}_{1 \mathrm{~A}}$ receptors after sense or antisense plasmid injection}

Autoradiographic experiments

$5-\mathrm{HT}_{1 \mathrm{~A}}$ receptor density measured by quantitative immunoautoradiography using polyclonal antibodies raised against the rat $5-\mathrm{HT}_{1 \mathrm{~A}}$ receptor sequence (El Mestikawy et al., 1990) showed no significant change in the DRN and the hippocampus, $8 \mathrm{~d}$ after intra-DRN injection of the sense or the antisense plasmid (Fig. 6, Table 2).

In contrast, the ability of 5-CT, a nonselective $5-\mathrm{HT}_{1 \mathrm{~A}}$ receptor agonist, to induce $\left[{ }^{35} \mathrm{~S}\right] \mathrm{GTP}-\gamma-\mathrm{S}$ binding was modified in the DRN but not the hippocampus after these treatments (Fig. 6, Table 2). Thus, the increase in $\left[{ }^{35} \mathrm{~S}\right] \mathrm{GTP}-\gamma$-S binding caused by $10 \mu \mathrm{M} 5-\mathrm{CT}$ was significantly higher $(+38 \%)$ in the DRN of rats injected with the sense plasmid, and lower $(-17 \%)$ in those injected with the short antisense plasmid, as compared with that measured in paired controls injected with the pRc-CMV nonrecombinant vector. In both the DRN and the hippocampus, the

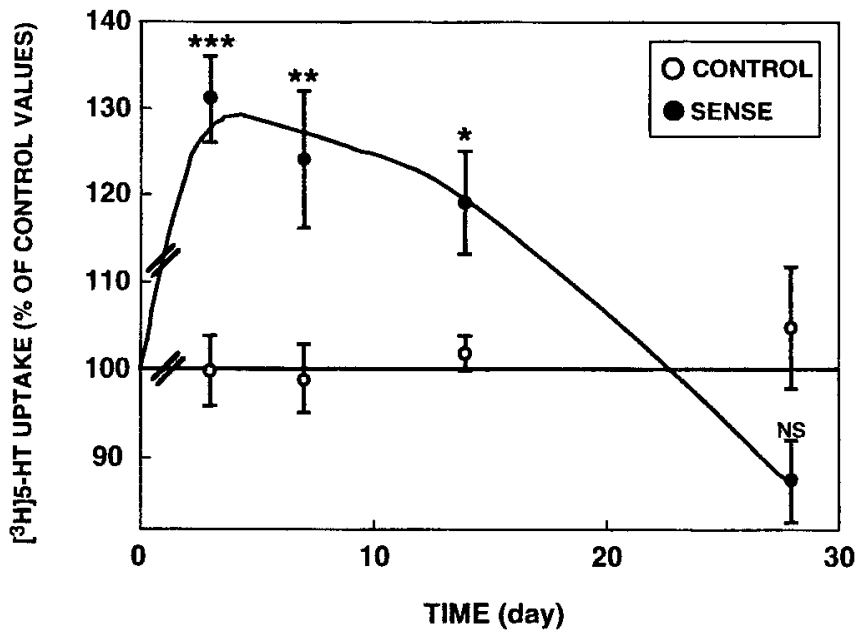

Figure 5. Time course of the effect of sense construct injection on 5-HTT activity in the hypothalamus. The sense or the nonrecombinant (control) plasmid was injected into the dorsal raphe nucleus, and rats were killed 3 , 7,14 , or 28 d later. $\left[{ }^{3} \mathrm{H}\right] 5$-HT synaptosomal uptake was measured in the hypothalamus. Each point is the mean \pm SEM of six independent determinations (one determination per rat). $\left[{ }^{3} \mathrm{H}\right] 5$-HT uptake is expressed as percentage of values determined in rats injected with the nonrecombinant plasmid $(233 \pm 12$ femtomoles per minute per milligram of protein; mean $\pm \mathrm{SEM} ; n=4)$. NS, Not significant; ${ }^{*} p<0.05 ;{ }^{* *} p<0.01$; *** $p<$ 0.005 as compared with paired-control values (Student's $t$ test).

stimulatory effect of $10 \mu \mathrm{M}$ 5-CT on $\left[{ }^{35} \mathrm{~S}\right] \mathrm{GTP}-\gamma$-S binding was completely inhibited by $10 \mu \mathrm{M}$ WAY 100,635 in the three groups of rats. Indeed, $\left[{ }^{35} \mathrm{~S}\right] \mathrm{GTP}-\gamma-\mathrm{S}$ binding in the presence of both 5-CT and WAY 100,635 was similar to the basal binding, which did not differ whether rats were injected with the sense, the antisense, or the nonrecombinant plasmid (data not shown).

\section{Electrophysiological experiments}

No significant differences between control rats and rats injected with either the sense or the antisense plasmid were observed concerning the spontaneous firing rate of 5-HT neurons in the DRN. However, the potency of the $5-\mathrm{HT}_{1 \mathrm{~A}}$ receptor agonist ipsapirone to inhibit, in a concentration-dependent manner, the discharge of these neurons was significantly decreased $8 \mathrm{~d}$ after injection of the antisense plasmid $\left(\mathrm{IC}_{50}=102 \pm 23 \mathrm{~nm}\right.$ vs $42 \pm 3$ nM in control rats; $n=3$ in each group; $p<0.05$ ). In contrast, no significant modification in the potency of ipsapirone was found in rats injected with the sense plasmid $\left(\mathrm{IC}_{50}=62 \pm 10 \mathrm{~nm}\right)$ (Fig. 7).

\section{Sleep-wakefulness rhythms after sense or antisense plasmid injection}

The overall amounts of W, SWS, and REMS per $24 \mathrm{hr}$ were similar whether rats were injected on the eighth day before the recording session with either the sense, the antisense, or the nonrecombinant plasmid. However, marked differences were noted in the circadian rhythm of sleep-wakefulness between rats injected with the antisense plasmid or the $\mathrm{pRc}-\mathrm{CMV}$ nonrecombinant vector. In particular, during the light period, an increase in the amounts of W $(+32 \pm 4 \% ; p<0.005)$ and a decrease in those of SWS $(-11 \pm$ $3 \% ; p<0.05)$ and REMS $(-28 \pm 15 \%$; NS) were found in rats injected with the antisense plasmid as compared with paired controls. In contrast, during the dark period, W was decreased $(-12 \pm$ $3 \% ; p<0.05$ ), and sleep was increased (SWS, $+19 \pm 8 \%$, NS; REMS, $+85 \pm 15 \% ; p<0.05)$ in the antisense plasmid-injected 
Table 1. Effects of intra-DRN injection of sense or antisense construct on 5-HT and 5-HIAA levels in the hypothalamus and the hippocampus

\begin{tabular}{|c|c|c|c|c|c|c|}
\hline & \multicolumn{2}{|c|}{ 5-HT (ng/mg prot) } & \multicolumn{2}{|c|}{ 5-HIAA (ng/mg prot) } & \multicolumn{2}{|c|}{ 5-HIAA/5-HT } \\
\hline & Control & Sense & Control & Sense & Control & Sense \\
\hline Hypothalamus & $5.10 \pm 0.15$ & $\begin{array}{l}5.36 \pm 0.20 \mathrm{NS} \\
(+5 \%)\end{array}$ & $2.91 \pm 0.09$ & $\begin{array}{l}3.86 \pm 0.17^{* * *} \\
(+33 \%)\end{array}$ & $0.57 \pm 0.02$ & $\begin{array}{l}0.72 \pm 0.02^{* *} \\
(+26 \%)\end{array}$ \\
\hline \multirow[t]{2}{*}{ Hippocampus } & $1.91 \pm 0.10$ & $\begin{array}{l}2.22 \pm 0.11^{*} \\
(+16 \%)\end{array}$ & $2.42 \pm 0.12$ & $\begin{array}{l}2.69 \pm 0.17 \mathrm{NS} \\
(+11 \%)\end{array}$ & $1.26 \pm 0.09$ & $\begin{array}{l}1.25 \pm 0.06 \mathrm{NS} \\
(-1 \%)\end{array}$ \\
\hline & Control & Antisense & Control & Antisense & Control & Antisense \\
\hline Hypothalamus & $5.50 \pm 0.28$ & $\begin{array}{l}3.36 \pm 0.36^{* * *} \\
(-39 \%)\end{array}$ & $2.81 \pm 0.17$ & $\begin{array}{l}2.38 \pm 0.14 \text { NS } \\
(-15 \%)\end{array}$ & $0.51 \pm 0.05$ & $\begin{array}{l}0.91 \pm 0.12^{* *} \\
(+79 \%)\end{array}$ \\
\hline Hippocampus & $2.22 \pm 0.26$ & $\begin{array}{l}1.58 \pm 0.11^{*} \\
(-29 \%)\end{array}$ & $2.35 \pm 0.09$ & $\begin{array}{l}2.23 \pm 0.16 \mathrm{NS} \\
(-5 \%)\end{array}$ & $1.05 \pm 0.08$ & $\begin{array}{l}1.47 \pm 0.13^{* *} \\
(+40 \%)\end{array}$ \\
\hline
\end{tabular}

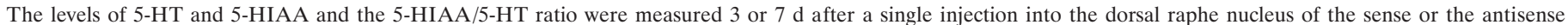

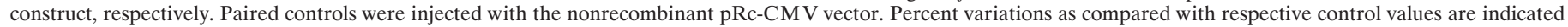
in parentheses. Results are the means \pm S.E.M. of values from $8-10$ rats.

NS, Nonsignificant; ${ }^{*} p<0.05 ;{ }^{*} p<0.01 ;{ }^{* *} p<0.005$ as compared with paired control values (Student's $t$ test).

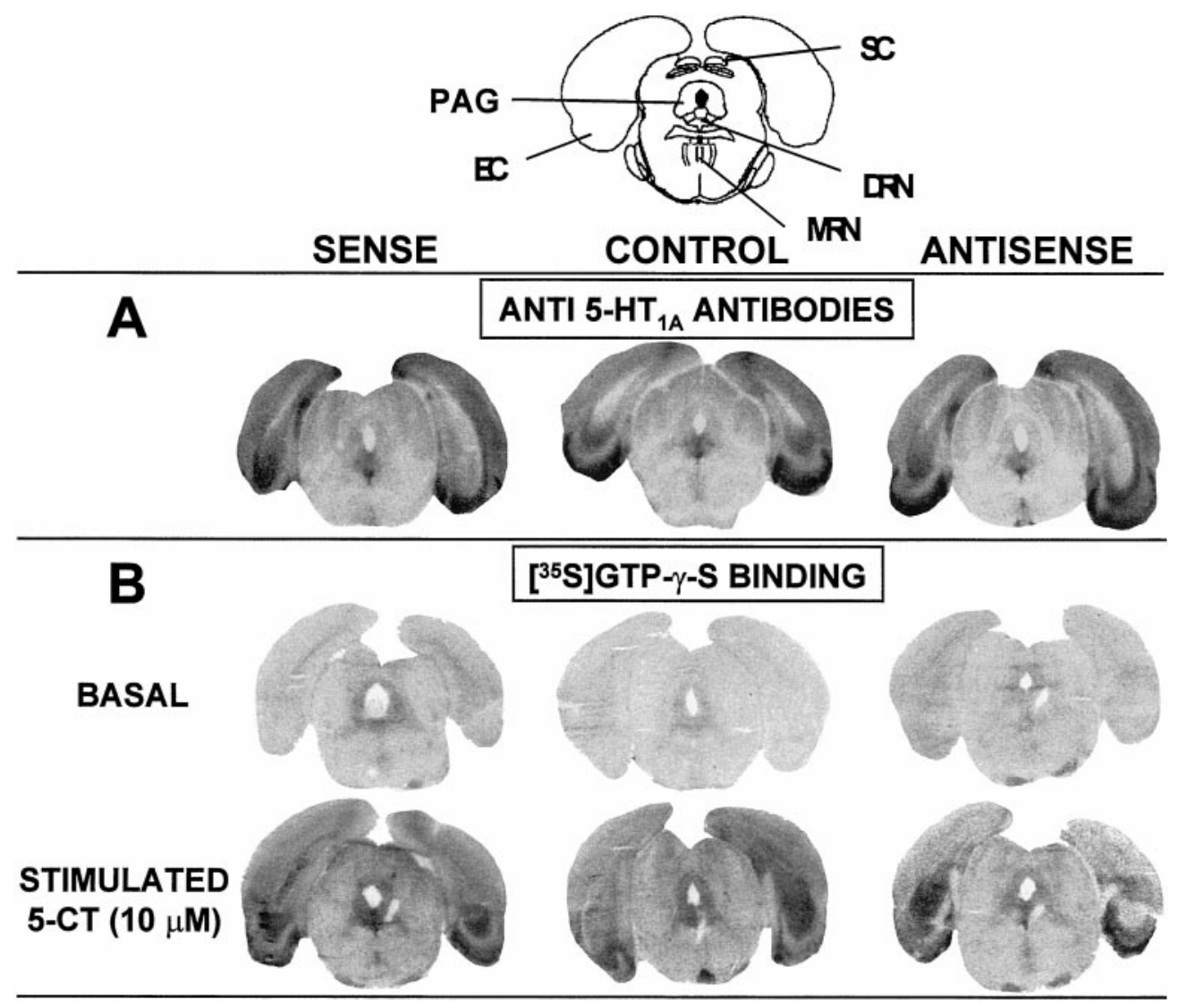

Figure 6. Autoradiographic analysis of $5-\mathrm{HT}_{1 \mathrm{~A}}$ receptors after injection of sense, antisense, or nonrecombinant (control) constructs into the dorsal raphe nucleus. Animals were killed $8 \mathrm{~d}$ after intra-DRN injection of either plasmid. Coronal sections $(20 \mu \mathrm{m})$ were made at the level of the dorsal raphe nucleus, following the stereotaxic atlas of Paxinos and Watson (1986) (plate 49). A, Representative immunoautoradiograms of brain sections labeled with specific anti-5- $\mathrm{HT}_{1 \mathrm{~A}}$ receptor antibodies. $B$, Autoradiograms of coronal sections labeled by $\left[{ }^{35} \mathrm{~S}\right] \mathrm{GTP}-\gamma-\mathrm{S}(50 \mathrm{pM})$ without (basal) or with (stimulated) 10 $\mu$ M 5-CT. Similar data have been obtained with sections from seven rats in each group (see Table 2). DRN, Dorsal raphe nucleus; $E C$, entorhinal cortex; $M R N$, median raphe nucleus; $P A G$, periaqueductal gray; $S C$, superior colliculi.

animals. These changes in the latter group, which were mostly restricted to the middle of the light and of the dark periods (data not shown), resulted in an overall decrease of the amplitude of the sleep-wakefulness circadian rhythm (Fig. 8). This phenomenon was particularly prominent for REMS because the same amounts of this sleep stage were found during the light and the dark periods in rats injected with the antisense plasmid. In contrast, as classically observed in normal rats, larger amounts of REMS were expressed during the light versus the dark period in animals injected with the nonrecombinant pRc-CMV plasmid. As shown in Figure 8, no modifications in the sleep-wakefulness circadian rhythm were noted in rats injected with the sense plasmid as compared with paired controls.

\section{DISCUSSION}

Our data demonstrated that it is possible to affect 5-HTT expression in the rat brain by nonviral gene transfer. We used PEI, a cationic polymer, to form complexes with plasmid DNA for this transfer because previous studies demonstrated its efficiency as gene vector in various cerebral cell types (Boussif et al., 1995; Abdallah et al., 1996; Goula et al., 1998; Martres et al., 1998). Another advantage of PEI is its apparent lack of cytotoxicity 
Table 2. Effects of intra-DRN injection of sense or antisense construct on 5-HT iA $_{\text {A }}$ receptors

\begin{tabular}{|c|c|c|c|c|}
\hline & \multicolumn{2}{|c|}{ Antibodies (O.D.) } & \multicolumn{2}{|c|}{$\begin{array}{l}{\left[{ }^{35} \mathrm{~S}\right] \mathrm{GTP}-\gamma-\mathrm{S}(\% \text { of stimulation with }} \\
10 \mu \mathrm{M} 5-\mathrm{CT})\end{array}$} \\
\hline & DRN & Hippocampus & DRN & Hippocampus \\
\hline Control & $11.3 \pm 0.4$ & $14.1 \pm 0.3$ & $+169 \pm 7$ & $+338 \pm 20$ \\
\hline Sense & $10.6 \pm 0.4 \mathrm{NS}$ & $13.9 \pm 1.3 \mathrm{NS}$ & $\begin{array}{l}+234 \pm 28 * \\
(+38 \%)\end{array}$ & $+371 \pm 52 \mathrm{NS}$ \\
\hline Antisense & $10.2 \pm 0.5 \mathrm{NS}$ & $14.2 \pm 0.3 \mathrm{NS}$ & $\begin{array}{l}+140 \pm 5^{*} \\
(-17 \%)\end{array}$ & $+321 \pm 20 \mathrm{NS}$ \\
\hline
\end{tabular}

Immunoautoradiographic labeling with anti-5- $\mathrm{HT}_{1 \mathrm{~A}}$ antibodies and $\left[{ }^{35} \mathrm{~S}\right] \mathrm{GTP}-\gamma-\mathrm{S}$ binding were measured in the DRN and the hippocampus $8 \mathrm{~d}$ after a single injection into the dorsal raphe nucleus of the sense, the antisense, or the nonrecombinant (control) plasmid. Results are expressed as optical density values (O.D. in arbitrary units) or percent of stimulation over basal of $\left[{ }^{35} \mathrm{~S}\right] \mathrm{GTP}-\gamma-\mathrm{S}$ binding in the presence of $10 \mu \mathrm{M}$ 5-CT. Each value is the mean \pm S.E.M. of seven independent determinations (each determination is the mean of data from six sections per rat).

NS, Nonsignificant; * $p<0.05$ as compared with paired control values (Student's $t$ test).

(Boussif et al., 1995; Abdallah et al., 1996; Martres et al., 1998), which was confirmed here. Indeed, all along the time course study, no modification in synaptosomal $\left[{ }^{3} \mathrm{H}\right] 5-\mathrm{HT}$ uptake (in the hypothalamus) was observed in paired-control rats injected with the nonrecombinant plasmid complexed with PEI as compared with noninjected intact rats; furthermore, the firing rate of DRN 5-HT cells and their sensitivity to $5-\mathrm{HT}_{1 \mathrm{~A}}$ autoreceptor-mediated inhibition were also identical in both groups of rats.

This transfer strategy, that we previously used for modifying DAT expression in brain (Martres et al., 1998), could be successfully extended to produce long-term changes in 5-HTT expression. Indeed, administration of the complex formed by the sense 5-HTT plasmid and PEI at six charge equivalents induced, $3 \mathrm{~d}$ later, a significant increase in 5-HTT labeling by $\left[{ }^{3} \mathrm{H}\right]$ citalopram, both in the DRN and in various forebrain areas. Conversely, administration of an antisense plasmid complexed with PEI induced, $7 \mathrm{~d}$ later, a significant decrease in 5-HTT labeling by $\left[{ }^{3} \mathrm{H}\right]$ citalopram in the same areas. These changes were associated with parallel modifications in: (1) 5-HTT immunolabeling by selective antibodies (Zhou et al., 1996) in the DRN and (2) $\left[{ }^{3} \mathrm{H}\right] 5-\mathrm{HT}$ synaptosomal uptake in forebrain areas. In the adult rat brain, 5-HTT is exclusively synthesized in serotoninergic neurons (Zhou et al., 1996), and the decrease in 5-HTT markers after antisense plasmid injection necessarily reflected the transfer of this construct into these neurons. In case of 5-HTT overexpression caused by the sense plasmid, the situation is less clear because "plasmid-PEI" complexes can enter glial cells as well as neurons (Goula et al., 1998). Therefore, some expression of 5-HTT by transfected glial cells within the DRN cannot be excluded. However, because of the limited diffusion of plasmidPEI complexes in brain parenchyma (Martres et al., 1998), 5-HTT overexpression in forebrain regions very probably resulted from the transport along 5-HT fibers of 5-HTT synthesized from the sense plasmid in DRN 5-HT cell bodies.

Time course studies showed that 5-HTT overexpression persisted for at least $14 \mathrm{~d}$ after a single injection of the sense construct-PEI complex. On the other hand, the downexpression of 5-HTT was already maximum as soon as on the third day after injection of the short antisense construct. In contrast, a significant downexpression of DAT could be detected only on the seventh day after injection of the corresponding antisense oligodeoxynucleotide or plasmid (Silvia et al., 1997; Martres et al., 1998). Such a difference suggests that 5-HTT has a shorter half-life than DAT, although these two membrane transporters are members of the same protein family.
As expected from functional alterations in 5-HT neurotransmission, administration of the sense construct induced, $3 \mathrm{~d}$ later, significant increases in both 5-HIAA levels and 5-HIAA/5-HT ratio in the hypothalamus, and in 5-HT levels in the hippocampus. Moreover, hypothalamic DOPAC levels also increased after this treatment. The latter change very probably resulted from primary modifications in 5-HT neurotransmission (through well known 5-HT-DA interactions; Di Mascio et al., 1998) because immunoautoradiographic labeling revealed no alterations in DAT expression after intra-DRN injection of either recombinant or nonrecombinant plasmids. Interestingly, such modifications in 5-HT and DA turnover are reminiscent of those reported after administration of tianeptine, an atypical tricyclic antidepressant that stimulates in vivo 5-HT uptake (Fattaccini et al., 1990; Frankfurt et al., 1995). Indeed, systemic injection of tianeptine has been shown to increase 5-HIAA and DOPAC levels in the hypothalamus, as well as 5-HT levels in the hippocampus (Fattaccini et al., 1990; De Simoni et al., 1992; Frankfurt et al., 1995; Marinesco et al., 1996).

On the other hand, 5-HT levels were decreased, and the 5-HIAA/5-HT ratio was increased in the hypothalamus and the hippocampus of rats injected with the antisense plasmid. Similar changes were reported in rats injected with D-fenfluramine, which releases 5-HT by reversing 5-HTT activity (Garattini et al., 1975; Fattaccini et al., 1991). The decreased 5-HT tissue levels observed after antisense construct administration are also reminiscent of that observed in knock-out mice lacking the 5-HTT (Bengel et al., 1998). Whether extracellular levels of 5-HT are increased in rats injected with this construct, like after fenfluramine treatment (Sabol et al., 1992) and in 5-HTT $-/-$ mice (Andrews et al., 1998), has to be addressed in future investigations. However, in contrast to that noted in the former two areas, modifications in 5-HTT activity were apparently not associated with alterations in 5-HT turnover in the striatum and the anterior cortex. Such differences further support the idea that the regulation of 5-HT synthesis and/or release exhibits regional variations possibly due to variable density and/or functional efficacy of terminal 5-HT autoreceptors from one brain area to another (Briley et al., 1997).

In the DRN, serotonergic neurons are negatively controlled by somatodendritic 5-HT 1A $_{\text {A }}$ autoreceptors (Sotelo et al., 1990; HajDahmane et al., 1991). Chronic increase in extracellular 5-HT levels by long-term treatment with SSRIs is well known to produce $5-\mathrm{HT}_{1 \mathrm{~A}}$ autoreceptor desensitization (Chaput et al., 1986; Le Poul et al., 1995, 2000). Therefore, analysis of the functional 

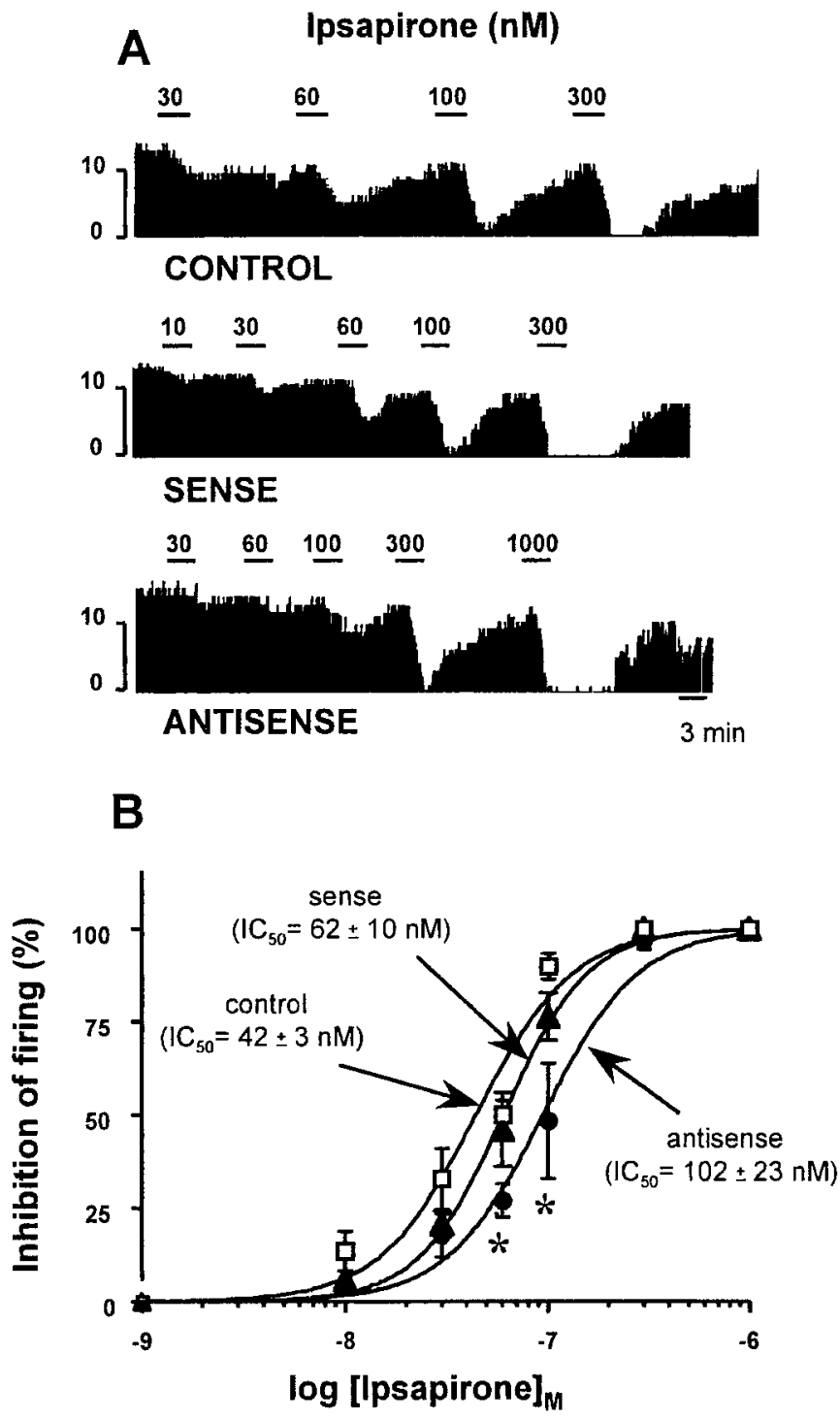

Figure 7. Effects of administration of sense or antisense plasmid on the potency of ipsapirone to depress the firing frequency of 5-HT neurons in the dorsal raphe nucleus. A, Integrated firing rate (spikes/10 sec) histograms of 5-HT neurons of the dorsal raphe nucleus in brainstem slices exposed to ipsapirone (10-1000 nM). Recordings were made $8 \mathrm{~d}$ after local injection of sense, antisense, or nonrecombinant (control) plasmid. Each horizontal bar represents bath application of ipsapirone for $3 \mathrm{~min}$ at the indicated concentration. $B$, Concentration-response curves of ipsapirone-induced inhibition of the firing rate of 5-HT neurons in brainstem slices. Results are expressed as a percentage of the baseline firing rate in paired-control rats (open squares) and in rats injected with the sense (dark triangles) or the antisense plasmid (dark circles). Each point is the mean \pm SEM of three to five independent determinations. $\mathrm{IC}_{50}( \pm$ SEM) values were calculated by nonlinear regression analysis, using Inplot 4. ${ }^{*} p<0.05$ as compared with paired-control rats (Student's $t$ test).

status of $5-\mathrm{HT}_{1 \mathrm{~A}}$ autoreceptors was used to assess possible longterm changes in extracellular 5-HT levels in rats injected with recombinant plasmids. At a time when 5-HTT expression was significantly modified, i.e., $8 \mathrm{~d}$ after injection of either construct, $5-\mathrm{HT}_{1 \mathrm{~A}}$ receptor immunolabeling by specific antibodies was altered nowhere in brain. In contrast, $5-\mathrm{HT}_{1 \mathrm{~A}}$ receptor-mediated increase in $\left[{ }^{35} \mathrm{~S}\right] \mathrm{GTP}-\gamma$-S binding by 5 -CT was significantly enhanced or reduced in the DRN after injection of the sense or antisense plasmid, respectively. Interestingly, such changes were

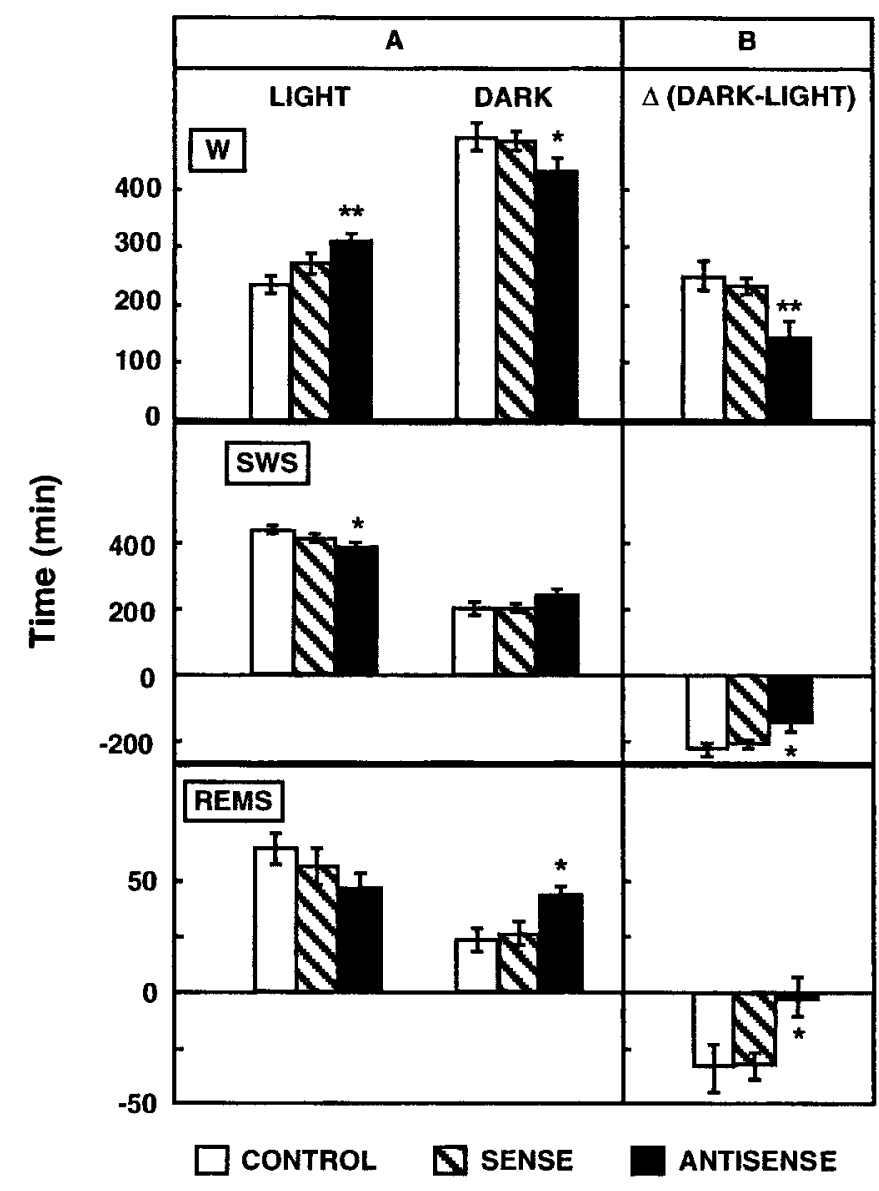

Figure 8. Effects of administration of the sense or the antisense plasmid on the circadian sleep-wakefulness rhythm. $A$, Quantitative analysis of $\mathrm{W}$, SWS, or REMS during light and dark periods was made $8 \mathrm{~d}$ after injection of sense, antisense, or nonrecombinant (control) constructs into the dorsal raphe nucleus. Each bar (amount of the corresponding vigilance state, in minutes per $12 \mathrm{hr}$ of the light or the dark period) is the mean \pm SEM of data obtained in seven rats. $B$, Difference in the amounts of each vigilance state between the dark and the light period (for each state, $\Delta=$ [minutes per $12 \mathrm{hr}$ of the dark period] - [min per $12 \mathrm{hr}$ of the light period]). Each bar is the mean \pm SEM of seven independent determinations. ${ }^{*} p<0.05$ and ${ }^{* *} p<0.005$ as compared with pairedcontrol rats (Student's $t$ test).

not observed in the hippocampus, in agreement with previous observations after chronic treatment with SSRIs (Le Poul et al., 2000) and in 5-HTT -/- mice (Fabre et al., 1998).

Further assessment of the functional status of $5-\mathrm{HT}_{1 \mathrm{~A}}$ autoreceptors by recording the electrical activity of DRN 5-HT neurons showed that the potency of the 5- $\mathrm{HT}_{1 \mathrm{~A}}$ agonist ipsapirone (HajDahmane et al., 1991) to inhibit the discharge of these neurons was reduced in rats injected with the antisense plasmid. This finding confirmed that 5-HTT downexpression was associated with $5-\mathrm{HT}_{1 \mathrm{~A}}$ autoreceptor desensitization, like that observed after chronic 5-HTT blockade by SSRIs (Chaput et al., 1986; Le Poul et al., 1995, 2000) or 5-HTT gene knock-out (Fabre et al., 1998). Such similarities emphasize the capacity of $5-\mathrm{HT}_{1 \mathrm{~A}}$ autoreceptors to adapt to the long-term enhancement in extracellular 5-HT levels that (probably) occurs under these various conditions. Interestingly, 5-HTT overexpression, which presumably decreases extracellular 5-HT concentration, did not affect the sensitivity of $5-\mathrm{HT}_{1 \mathrm{~A}}$ autoreceptors in the DRN of rats injected with the sense plasmid, in spite of a local increase in $5-\mathrm{HT}_{1 \mathrm{~A}^{-}}$ 
mediated $\left[{ }^{35} \mathrm{~S}\right] \mathrm{GTP}-\gamma$-S binding. Because the latter change concerned the whole pool of various types of G-proteins functionally coupled with 5-HT $1 \mathrm{~A}$ autoreceptors (Hamon, 1997), this discrepancy suggests that, among them, the G-protein selectively involved in $5-\mathrm{HT}_{1 \mathrm{~A}}$ autoreceptor-mediated inhibition of serotonergic neuron firing might not be concerned by the increased $\left[{ }^{35} \mathrm{~S}\right] \mathrm{GTP}-\gamma-\mathrm{S}$ binding. Studies of individual types of G-proteins are needed to identify which of them were actually responsible for the $5-\mathrm{HT}_{1 \mathrm{~A}}$-mediated increase in $\left[{ }^{35} \mathrm{~S}\right] \mathrm{GTP}-\gamma-\mathrm{S}$ binding in the DRN of sense plasmid-injected rats.

In line with the well established involvement of serotoninergic systems in sleep regulation (Jouvet, 1969), our data indicate that 5-HTT downexpression affected sleep-wakefulness rhythms. However, in agreement with the lack of effect of tianeptine on sleep in rats (Lejeune et al., 1988), no changes in sleep-wakefulness circadian rhythm were noted after increased 5-HTT expression. In contrast, a significant decrease in the amplitude of circadian sleep-wakefulness rhythm was observed in rats injected with the antisense plasmid. The 5-HTT is highly expressed in the hypothalamus (Amir et al., 1997), particularly in the suprachiasmatic nucleus, where the circadian oscillator is localized (Miller et al., 1996). Lesion of the suprachiasmatic nucleus is known to abolish circadian rhythms in the rat (Ibuka et al., 1977; Mouret et al., 1978). Thus, it can be hypothesized that antisense plasmidinduced changes in 5-HT neurotransmission, particularly in the hypothalamus, might affect the activity of the circadian oscillator, thereby altering sleep-wakefulness rhythms. Interestingly, 5-HT uptake blockade by SSRIs has also been reported to increase W and decrease SWS and REMS during the light period (Sommerfelt et al., 1987; Maudhuit et al., 1994).

In conclusion, our data show the efficiency of nonviral gene transfer to modulate 5-HTT expression in the rat brain. The fact that $20-30 \%$ variations in 5-HTT density are enough to induce significant alterations in 5-HT neurotransmission further underlines the key role of 5-HT reuptake in the homeostatic regulation of the 5-HT system.

\section{REFERENCES}

Abdallah B, Hassan A, Benoist C, Goula D, Behr J, Demeneix BA (1996) A powerful nonviral vector for in vivo gene transfer into the adult mammalian brain: polyethylenimine. Hum Gene Ther 7:1947-1954.

Adrien J, Dugovic C, Martin P (1991) Sleep-wakefulness patterns in the helpless rat. Physiol Behav 49:257-262.

Aghajanian GK, Bloom FE (1967) Localization of tritiated serotonin in rat brain by electron microscopic radioautography. J Pharmacol Exp Ther 156:23-30.

Amir S, Robinson B, Ratovitski T, Rea MA, Stewart J, Simantov R (1997) A role for serotonin in the circadian system revealed by the distribution of serotonin transporter and light-induced fos immunoreactivity in the suprachiasmatic nucleus and intergeniculate leaflet. Neuroscience 84:1059-1073.

Andrews AM, Wichems CH, Li Q, Heils A, Lesch KP, Murphy DL (1998) A microdialysis study of the effects of high $\mathrm{K}^{+}$and paroxetine on extracellular serotonin concentrations in serotonin transporter knock-out mice. Soc Neurosci Abstr 24:1112.

Auerbach SB, Hjorth S (1995) Effect of chronic administration of the selective serotonin (5-HT) uptake inhibitor citalopram on extracellular 5-HT and apparent autoreceptor sensitivity in rat forebrain in vivo. Naunyn Schmiedebergs Arch Pharmacol 352:597-606.

Bengel D, Murphy DL, Andrews AN, Wichems CH, Feltner D, Heils A, Mössner R, Westphal H, Lesch KP (1998) Altered brain serotonin homeostasis and locomotor insensitivity to 3,4-methylenedioxymethamphetamine ("ecstasy") in serotonin transporter-deficient mice. Mol Pharmacol 53:649-655.

Blakely RD, Berson HE, Fremeau RT, Caron MG, Peck MM, Prince HK, Bradley CC (1991) Cloning and expression of a functional serotonin transporter from rat brain. Nature 354:66-70.
Boussif O, Lezoualch F, Zanta MA, Mergny MD, Scherman D, Demeneix B, Behr JP (1995) A versatile vector for gene and oligonucleotide transfer into cells in culture and in vivo: polyethylenimine. Proc Natl Acad Sci USA 92:7297-7301.

Briley M, Chopin P, Marien M, Moret C (1997) Functional neuropharmacology of compounds acting at 5- $\mathrm{HT}_{1 \mathrm{~B} / \mathrm{D}}$ receptors. In: Serotoninergic neurons and 5-HT receptors in the CNS, Handbook of experimental pharmacology, Vol 129 (Baumgarten HG, Göthert M, eds), pp 269-291. Berlin: Springer.

Chaput Y, De Montigny C, Blier P (1986) Effects of a selective 5-HT reuptake blocker, citalopram, on the sensitivity of 5-HT autoreceptors: electrophysiological studies in the rat brain. Naunyn Schmiedebergs Arch Pharmacol 333:342-348.

D'Amato RJ, Largent BL, Snowman AM, Snyder SH (1987) Selective labeling of serotonin uptake sites in rat brain by $\left[{ }^{3} \mathrm{H}\right]$ citalopram contrasted to labeling of multiple sites by $\left[{ }^{3} \mathrm{H}\right]$ imipramine. J Pharmacol Exp Ther 242:364-371.

De Simoni MG, De Luigi A, Clavenna A, Manfridi A (1992) In vivo studies on the enhancement of serotonin uptake by tianeptine. Brain Res 574:93-97.

Dechant KL, Clissold SP (1991) Paroxetine: a review of its pharmacodynamic and pharmacokinetic properties, and therapeutic potential in depressive illness. Drugs 41:225-253.

Descarries L, Watkins KC, Garcia S, Beaudet A (1982) The serotonin neurons in nucleus raphe dorsalis of adult rat: a light and electron microscope radioautographic study. J Comp Neurol 207:239-254.

Di Mascio M, Di Giovanni G, Di Matteo V, Prisco S, Esposito E (1998) Selective serotonin reuptake inhibitors reduce the spontaneous activity of dopaminergic neurons in the ventral tegmental area. Brain Res Bull 46:547-554.

Di Scenna P (1987) Method and myth in maintaining brain slices. In: Brain slices: fundamentals, applications and implications (Schurr A, Teyler T, Tseng M, eds), pp 10-21. Basel: Karger.

Dupuis DS, Palmier C, Colpaert FC, Pauwels PJ (1998) Autoradiography of $5-\mathrm{HT}_{1 \mathrm{~A}}$ receptor-activated G-protein in guinea-pig brain sections by agonist-stimulated $\left[{ }^{35} \mathrm{~S}\right] \mathrm{GTP} \gamma \mathrm{S}$ binding. J Neurochem 70:1258-1268.

El Mestikawy S, Riad M, Laporte AM, Vergé D, Daval G, Gozlan H, Hamon M (1990) Production of specific anti-rat 5-HT ${ }_{1 \mathrm{~A}}$ receptor antibodies in rabbits injected with a synthetic peptide. Neurosci Lett 118:189-192.

Fabre V, Rioux A, Lanfumey L, Lesch KP, Hamon M, Martres MP (1998) Adaptive changes in central 5-HT receptors in knock-out mice lacking the 5-HT transporter. Soc Neurosci Abstr 24:1113.

Fattaccini CM, Bolaños-Jimenez F, Gozlan H, Hamon M (1990) Tianeptine stimulates uptake of 5-hydroxytryptamine in vivo in the rat brain. Neuropharmacology 29:1-8.

Fattaccini CM, Gozlan H, Hamon M (1991) Differential effects of D-fenfluramine and $p$-chloroamphetamine on H75/12-induced depletion of 5-hydroxytryptamine and dopamine in the rat brain. Neuropharmacology 30:15-23.

Frankfurt M, McKittrick CR, McEwen BS, Luine VN (1995) Tianeptine treatment induces regionally specific changes in monoamines. Brain Res 696:1-6.

Fuller RW, Perry KN, Molloy B (1975) Effect of 3-( $p$ trifluoromethylphenoxy)- $N$-methyl-3-phenylpropylamine on the depletion of brain serotonin by 4-chloro-amphetamine. J Pharmacol Exp Ther 193:796-803.

Garattini S, Buzco W, Jori A, Samanin R (1975) The mechanism of action of fenfluramine. Postgrad Med J 51:27-35.

Gérard C, Langlois X, Gingrich J, Doucet E, Vergé D, Kia HK, Raisman R, Gozlan H, El Mestikawy S, Hamon M (1994) Production and characterization of polyclonal antibodies recognizing the intracytoplasmic third loop of the 5-hydroxytryptamine ${ }_{1 \mathrm{~A}}$ receptor. Neuroscience 62:721-739.

Goula D, Remy JS, Erbacher P, Wasowicz M, Levi G, Abdallah B, Demeinex B (1998) Size, diffusibility and transfection performance of linear PEI/DNA complexes in the mouse central nervous system. Gene Ther 5:712-717.

Green AR, Cross AJ, Goodwin GM (1995) Review of the pharmacology and clinical pharmacology of 3,4-methylenedioxymethamphetamine (MDMA or "Ecstasy"). Psychopharmacology 119:247-260.

Haj-Dahmane S, Hamon M, Lanfumey L (1991) $\mathrm{K}^{+}$channel and 5 -hydroxy-tryptamine ${ }_{1 \mathrm{~A}}$ autoreceptor interactions in the rat dorsal ra- 
phe nucleus: an in vitro electrophysiological study. Neuroscience 41:495-505.

Hamon M (1997) The main features of central 5- $\mathrm{HT}_{1 \mathrm{~A}}$ receptors. In: Serotoninergic neurons and 5-HT receptors in the CNS, Handbook of experimental pharmacology, Vol 129 (Baumgarten HG, Göthert M, eds), pp 239-268. Berlin: Springer.

Hamon M, Fattaccini CM, Adrien J, Gallissot MC, Martin P, Gozlan H (1988) Alterations of central serotonin and dopamine turnover in rats treated with ipsapirone and other 5-hydroxytryptamine ${ }_{1 \mathrm{~A}}$ agonists with potential anxiolytic properties. J Pharmacol Exp Ther 246:745-752.

Ibuka N, Inouye ST, Kawamura H (1977) Analysis of sleep-wakefulness rhythms in male rats after suprachiasmatic nucleus lesions and ocular enucleation. Brain Res 122:33-47.

Invernizzi R, Bramante M, Samanin R (1995) Extracellular concentrations of serotonin in the dorsal hippocampus after acute and chronic treatment with citalopram. Brain Res 696:62-66.

Jouvet M (1969) Biogenic amines and the states of sleep. Science 163:32-41.

Laitinen JT, Jokinen M (1998) Guanosine 5' -(gamma- $\left[{ }^{35}\right.$ S]thio)triphosphate autoradiography allows selective detection of histamine $\mathrm{H} 3$ receptor-dependent $\mathrm{G}$ protein activation in rat brain tissue sections. J Neurochem 71:808-816.

Le Poul E, Laaris N, Doucet E, Laporte AM, Hamon M, Lanfumey L (1995) Early desensitization of somato-dendritic 5-HT $\mathrm{HA}_{1 \mathrm{~A}}$ autoreceptors in rats treated with fluoxetine or paroxetine. Naunyn Schmiedebergs Arch Pharmacol 352:141-148.

Le Poul E, Boni C, Hanoun N, Laporte AM, Laaris N, Chauveau J, Hamon M, Lanfumey L (2000) Differential adaptation of brain $5-\mathrm{HT}_{1 \mathrm{~A}}$ and $5-\mathrm{HT}_{1 \mathrm{~B}}$ receptors and 5-HT transporter in rats treated chronically with fluoxetine. Neuropharmacology 39:110-122.

Lejeune F, Poignant J, Reure H (1988) Electrophysiological study of tianeptine, a new enhancer of serotonin uptake with antidepressant activity. Neurophysiol Clin 18:369-381.

Lowry OH, Rosebrough NJ, Farr A, Randall RJ (1951) Protein measurement with the Folin phenol reagent. J Biol Chem 193:265-275.

Marinesco S, Poncet L, Debilly G, Jouvet M, Cespuglio R (1996) Effects of tianeptine, sertraline and clomipramine on brain serotonin metabolism: a voltametric approach in the rat. Brain Res 736:82-90.

Martres MP, Demeneix B, Hanoun N, Hamon M, Giros B (1998) Upand down-expression of the dopamine transporter by plasmid DNA transfer in the rat brain. Eur J Neurosci 10:3607-3616.

Maudhuit C, Jolas T, Lainey E, Hamon M, Adrien J (1994) Effects of acute and chronic treatment with amoxapine and cericlamine on the sleep-wakefulness cycle in the rat. Neuropharmacology 33:1017-1025.

McPherson GA (1985) Kinetics, EBDA, Ligand, Lowry. A collection of radioligand binding analysis programs. Cambridge, UK.

Miller JD, Morin LP, Schwartz WJ, Moore RY (1996) New insights into the mammalian circadian clock. Sleep 8:641-667.

Mouret J, Coindet J, Debilly G, Chouvet G (1978) Suprachiasmatic nuclei lesions in the rat: alterations in sleep circadian rhythms. Electroencephalogr Clin Neurophysiol 15:102-108.

Paxinos P, Watson C (1986) The rat brain in stereotaxic coordinates, Ed 2. London: Academic.

Pifl C, Giros B, Caron MG (1993) Dopamine transporter expression confers cytotoxicity to low doses of the parkinsonism-inducing neurotoxin 1-methyl-4-phenylpyridinium. J Neurosci 13:4246-4253.

Pineyro G, Deveault L, Blier P, Dennis T, de Montigny C (1995a) Effect of acute and prolonged tianeptine administration on the 5-HT transporter: electrophysiological, biochemical and radioligand binding studies in the rat brain. Naunyn Schmiedebergs Arch Pharmacol 351:111-118.

Pineyro G, Deveault L, de Montigny C, Blier P (1995b) Effect of prolonged administration of tianeptine on 5-HT neurotransmission: an electrophysiological study in the rat hippocampus and dorsal raphe. Naunyn Schmiedebergs Arch Pharmacol 351:119-125.

Rocha BA, Fumagalli F, Gainetdinov RR, Jones SR, Ator R, Giros B, Miller GW, Caron MG (1998a) Cocaine self-administration in dopamine-transporter knockout mice. Nat Neurosci 1:132-137.

Rocha BA, Scearce-Levie K, Lucas JJ, Hiroi N, Castanon N, Crabbe JC, Nestler EJ, Hen R (1998b) Increased vulnerability to cocaine in mice lacking the serotonin-1B receptor. Nature 393:175-178.

Sabol KE, Richards JB, Seiden LS (1992) Fluoxetine attenuates the D,L-fenfluramine-induced increase in extracellular serotonin as measured by in vivo dialysis. Brain Res 585:421-424.

Silvia CP, Jaber M, King GR, Ellinwood EH, Caron MG (1997) Cocaine and amphetamine elicit differential effects in rats with a unilateral injection of dopamine transporter antisense oligonucleotides. Neuroscience 76:737-747.

Sim LJ, Selley DE, Xiao R, Childers SR (1996) Differences in G-protein activation by $\mu$ - and $\partial$-opioid and cannabinoid receptors in rat striatum. Eur J Pharmacol 307:97-105.

Sommerfelt L, Hauge ER, Ursin R (1987) Similar effect on REM sleep but differential effect on slow wave sleep of the two 5-HT uptake inhibitors zimeldine and alaproclate in cats and rats. J Neural Transm 68:127-144.

Sora I, Wichems C, Takahashi N, Li XF, Zeng Z, Revay R, Lesch KP, Murphy DL, Uhl GR (1998) Cocaine reward models: conditioned place preference can be established in dopamine- and in serotonintransporter knock-out mice. Proc Natl Acad Sci USA 95:7699-7704.

Sotelo C, Cholley B, El Mestikawy S, Gozlan H, Hamon M (1990) Direct immunohistochemical evidence of the existence of $5-\mathrm{HT}_{1 \mathrm{~A}}$ autoreceptors on serotonergic neurons in the midbrain raphe nuclei. Eur J Neurosci 2:1144-1154.

Thomas DR, Nelson DR, Johnson AM (1987) Biochemical effects of the antidepressant paroxetine, a specific 5-hydroxytryptamine uptake inhibitor. Psychopharmacology 93:193-200.

VanderMaelen CP, Aghajanian GK (1983) Electrophysiological and pharmacological characterization of serotoninergic dorsal raphe neurons recorded extracellularly and intracellularly in rat brain slices. Brain Res 289:109-119.

Waeber C, Moskowitz MA (1997) 5-Hydroxytryptamine ${ }_{1 \mathrm{~A}}$ and 5-hydroxytryptamine ${ }_{1 \mathrm{~B}}$ receptors stimulate $\left[{ }^{35} \mathrm{~S}\right]$ guanosine-5'-O-(3thio)triphosphate binding to rodent brain sections as visualized by in vitro autoradiography. Mol Pharmacol 52:623-631.

Zhou FC, Xu Y, Bledsoe S, Lin R, Kelley MR (1996) Serotonin transporter antibodies: production, characterization, and localization in the brain. Brain Res Mol Brain Res 43:267-278. 